\title{
Removal of antibiotics (sulfamethazine, tetracycline and chloramphenicol) from aqueous solution by raw and nitrogen plasma modified steel shavings
}

\author{
Van Son Tran ${ }^{\mathrm{a}}$, Huu Hao Ngo ${ }^{\mathrm{a}}$, , Wenshan Guo ${ }^{\mathrm{a}}$, Cuong Ton-That ${ }^{\mathrm{b}}$, Jianxin $\mathrm{Li}^{\mathrm{c}}$, Jixiang Li ${ }^{\mathrm{d}}$, Yi Liu ${ }^{\mathrm{d}}$ \\ ${ }^{a}$ Centre for Technology in Water and Wastewater, School of Civil and Environmental Engineering, \\ University of Technology Sydney, Broadway, NSW 2007, Australia \\ ${ }^{b}$ School of Mathematical and Physical Sciences, University of Technology Sydney, Broadway, NSW \\ 2007, Australia \\ ${ }^{c}$ State Key Laboratory of Hollow Fiber Membrane Materials and Processes, School of Materials \\ Science and Engineering, Tianjin Polytechnic University, Tianjin 300387, P. R. China \\ ${ }^{d}$ Shanghai Advanced Research Institute, Chinese Academy of Science, Haike Road, Pudong, Shanghai, \\ P.R. China \\ * Correspondence author. Email address: h.ngo@uts.edu.au; Tel: +61 29514 2745; Fax: + 612 \\ 95147803.
}

\begin{abstract}
The removal of sulfamethazine (SMT), tetracycline (TC) and chloramphenicol (CP) from synthetic wastewater by raw $\left(\mathrm{M}_{3}\right)$ and nitrogen plasma modified steel shavings $\left(\mathrm{M}_{3}-\mathrm{plN} \mathrm{N}_{2}\right)$ was investigated using batch experiments. The adsorption kinetics could be expressed by both pseudo-first-order kinetic (PFO) and pseudo-second-order kinetic (PSO) models, where correlation coefficient $r^{2}$ values were high. The values of PFO rate constant $k_{1 p}$ and PSO rate constant $\mathrm{k}_{2 \mathrm{p}}$ decreased as $\mathrm{SMT}_{-} \mathrm{M}_{3}>\mathrm{SMT}-\mathrm{M}_{3}-\mathrm{plN}_{2}>$ TC-M $-\mathrm{M}_{3}-\mathrm{plN}_{2}>$ TC- $\mathrm{M}_{3}>C P-\mathrm{M}_{3}>\mathrm{CP}-\mathrm{M}_{3}-$ $\mathrm{plN}_{2}$ and SMT-M $>$ SMT-M $-\mathrm{plN}_{2}>$ TC-M $>$ TC-M $-\mathrm{plN}_{2}>\mathrm{CP}-\mathrm{M}_{3}>\mathrm{CP}-\mathrm{M}_{3}-\mathrm{plN}_{2}$, respectively. Solution $\mathrm{pH}$, adsorbent dose and temperature exerted great influences on the adsorption process. The plasma modification with nitrogen gas cleaned and enhanced 1.7-fold the surface area and 1.4-fold the pore volume of steel shavings. Consequently, the removal capacity of SMT, TC, CP on the adsorbent rose from 2519.98 to $2702.55,1720.20$ to 2158.36 , and 2772.81 to $2920.11 \mu \mathrm{g} / \mathrm{g}$, respectively. Typical chemical states of iron (XPS in Fe2p3 region) in the adsorbents which are mainly responsible for removing antibiotics through hydrogen bonding, electrostatic and non- electrostatic interactions and redox reaction were as follows: $\mathrm{Fe}_{3} \mathrm{O}_{4} / \mathrm{Fe}^{2+}, \mathrm{Fe}_{3} \mathrm{O}_{4} / \mathrm{Fe}^{3+}, \mathrm{FeO} / \mathrm{Fe}^{2+}$ and $\mathrm{Fe}_{2} \mathrm{O}_{3} / \mathrm{Fe}^{3+}$.
\end{abstract}

Keywords: sulfamethazine, tetracycline, chloramphenicol, steel shavings, nitrogen plasma modified steel shavings 


\section{Introduction}

Water pollution by antibiotics has become a widespread environmental problem (Homem and Santos, 2011). The chemicals are expansively used in human and veterinary medicine for inhibiting illness (Sapkota et al., 2008). Recent studies have shown that a number of antibiotics are detected in surface and groundwater (Homem and Santos, 2011). Most antibiotics enter the environment, notably in the aquatic matrix, through discharge or disposal from medical, municipal, and agricultural sources (Daughton and Ternes, 1999; Sapkota et al., 2008). Even low concentrations of antibiotics in water can pose serious problems to the ecosystem such as their potential risks of environmental toxicity and promote microbial resistance (Ahmed et al., 2015; Homem and Santos, 2011).

Some typical antibiotics were selected in the present study including sulfamethazine (SMT), tetracycline (TC) and chloramphenicol (CP). SMT is a compound belonging to the sulphonamide group. SMT is usually used in veterinary medicine or livestock feeds for cattle and swine, and can be detected at high concentration in aqueous solution due to soil's poor ability to adsorb it (Aust et al., 2010; Wegst-Uhrich et al., 2014). TC, which belongs to the tetracyclines group of antibiotics, is also applied to livestock as additives to combat diseases (Chen et al., 2011). CP is an antibiotic commonly utilized in veterinary clinics (Nie et al., 2015). Chemical structure and properties of three studied compounds are displayed in Table 1. The appearance of the antibiotics in water results in several side effects such as aplastic anemia. While being banned from application to food-producing animals in developed countries, these chemicals are still used in many developing nations due to their low cost, effectiveness and availability (Sapkota et al., 2008). Thus, developments in efficient and cost-effective techniques for the removal of such compounds from water are necessary (Chen et al., 2011). 
Recently, a variety of methods to remove antibiotics and other pharmaceuticals from aquatic matrix such as advanced oxidation processes, combined chemical/biological treatment, aerobic digestion integrated with activated carbon, ion exchange, coagulation, flocculation, sedimentation, ultraviolet irradiation, have been attempted (Adams et al., 2002; Homem and Santos, 2011; Qiang et al., 2013; Nie et al., 2015). In comparison with other methods, adsorption using cost-effective adsorbents is considered an effective process that removes antibiotics from aqueous solution (Homem and Santos, 2011). The advantage of adsorption is removing $\mathrm{ABs}$ instead of producing potentially more dangerous metabolites (Putra et al., 2009; Homem and Santos, 2011). The technique also effectively eliminates contaminants at very low concentration (less than $1 \mathrm{mg} / \mathrm{L}$ ) (Putra et al., 2009). 
Table 1 Chemical structure and properties of the study antibiotics (Ahmed et al., 2015; Adams et al., 2002; Homem and Santos, 2011; Xia et al., 2014;

Pubchem, 2017)

\begin{tabular}{|c|c|c|c|c|c|c|}
\hline $\begin{array}{l}\text { Compound, } \\
\text { CAS number }\end{array}$ & $\begin{array}{l}\text { Molecular } \\
\text { formular, } \\
\text { weight }\end{array}$ & $\begin{array}{l}\text { Logkow, } \\
\text { pKa, } \\
\text { Solubility }\end{array}$ & $\begin{array}{l}\text { Analysis } \\
\text { wave } \\
\text { length } \\
\end{array}$ & Possible structure & Core structure & Treatment methods \\
\hline $\begin{array}{l}\text { Sulfamethazine } \\
57-68-1\end{array}$ & $\begin{array}{l}\mathrm{C}_{12} \mathrm{H}_{14} \mathrm{~N}_{4} \mathrm{O}_{2} \mathrm{~S} \\
278.34\end{array}$ & $\begin{array}{l}0.14 / 0.28 \\
2.65 / 7.65 \\
4.3\left(10^{2}\right)\end{array}$ & 275 & $\mathrm{H}^{\prime \prime}$ & $\begin{array}{l}\text { It is characterized by } \\
\text { sulfonyl group } \\
\text { connected to an amine } \\
\text { group }\end{array}$ & $\begin{array}{l}\text { Coagulation, flocculation, } \\
\text { sedimentation, excess lime, } \\
\text { soda ash, softening, } \\
\text { powdered activated carbon } \\
\text { sorption, chlorination, } \\
\text { ozonation, direct photolysis, } \\
\text { ion exchange, reverse } \\
\text { osmosis, nanofiltration, } \\
\text { semiconductor } \\
\text { photocatalysis, photo-fenton }\end{array}$ \\
\hline $\begin{array}{l}\text { Tetracycline } \\
60-54-8\end{array}$ & $\begin{array}{l}\mathrm{C}_{22} \mathrm{H}_{24} \mathrm{~N}_{2} \mathrm{O}_{8} \cdot \mathrm{HCl} \\
444.43\end{array}$ & $\begin{array}{l}-1.37 \\
3.3 \\
8.3\end{array}$ & 260 & H & $\begin{array}{l}\text { This antibiotic contains } \\
\text { an octrahydronaphtacene } \\
\text { ring skeleton, consisting } \\
\text { of } 4 \text { fused rings }\end{array}$ & $\begin{array}{l}\text { Ion exchange, nanofiltration, } \\
\text { coagulation, adsorption with } \\
\text { activated carbon, adsorption } \\
\text { with aluminum oxide, } \\
\text { semiconductor } \\
\text { photocatalysis, photo- } \\
\text { fenton, direct photolysis }\end{array}$ \\
\hline $\begin{array}{l}\text { Chloramphenicol } \\
56-75-7\end{array}$ & $\begin{array}{l}\mathrm{C}_{12} \mathrm{H}_{12} \mathrm{Cl}_{2} \mathrm{~N}_{2} \mathrm{O}_{5} \\
323.13\end{array}$ & $\begin{array}{l}1.14 \\
- \\
5.5^{2}\end{array}$ & $272 / 278$ & & $\begin{array}{l}\text { It contains a } \\
\text { nitrobenzene moiety } \\
\text { connected to a propanol } \\
\text { group as well as an } \\
\text { amino group binding a } \\
\text { derivative of } \\
\text { dichloroacetic acid }\end{array}$ & $\begin{array}{l}\text { Semiconductor } \\
\text { photocatalysis, nano zero- } \\
\text { valent iron, adsorption, } \\
\text { advanced oxidation }\end{array}$ \\
\hline
\end{tabular}


Among the various kinds of adsorbents, iron, particularly in the zero-valent $\left(\mathrm{Fe}^{0}\right)$ and oxide forms, does function as a good candidate due to its adsorption ability and abundance (Cundy et al., 2008, Aredes et al., 2012, Pouran et al., 2014). Some iron-based adsorbents have been used for removing antibiotics from water; for example, persulfate activated by $\mathrm{Fe}^{2+}$ and zerovalent iron, microscale zero-valent iron, nanoscale zero-valent iron (Ghauch et al., 2009; Xia et al., 2014; Nie et al., 2015). Also, iron-based adsorbents often have a magnetic characteristic and consequently, they offer advantages in solid-liquid separation processes under a magnetic field (Hua et al., 2012). Using adsorbents from wastes or by-products of agricultural, municipal and industrial sectors can reduce the quantity of solid waste, coupling with an increase in the value of the materials. Steel shavings ( $\mathrm{StS})$, a magnetic waste that is generated with a huge amount from steel processing industry, contain large amounts of zerovalent iron and iron oxides. Hence, studies on the utilization of steel shavings to abate antibiotics from aqueous solution are urgently required. Moreover, one of the most promising modification methods for iron-based adsorbents is plasma cleaning (Fig. 1). When exposing the iron to a plasma generated in a vacuum, the surface of the adsorbent is bombarded. It leads to adventitious hydrocarbons being removed from the iron surface and enhances the iron surface available for adsorption processes. The selection of gas to produce the plasma is important to produce good adsorbent (Deiries et al., 2005). Oxygen is effective in removing hydrocarbons both physically and chemically on the surfaces of oxidation-resistant metals such as aluminum and stainless steel (Deiries et al., 2005). However, when using a material prone to oxidation as iron, inert gasses, for instance argon and nitrogen, can serve to generate the plasma with the purpose of achieving the same result without further oxidizing the sample. Moreover, the cost of nitrogen is considerably cheaper than that of argon; therefore, the application of nitrogen plasma is more feasible. Thus, plasma with nitrogen was used to modify the steel shavings' surface. 
In general, this study aimed to develop a cost-effective adsorbent from steel shavings for the removal of antibiotics from water. Gas plasma (with nitrogen) was employed to improve the efficiency of antibiotics removal from aqueous solution. The technique modifies the unique surface properties of materials without affecting their bulk properties.

RF Generator

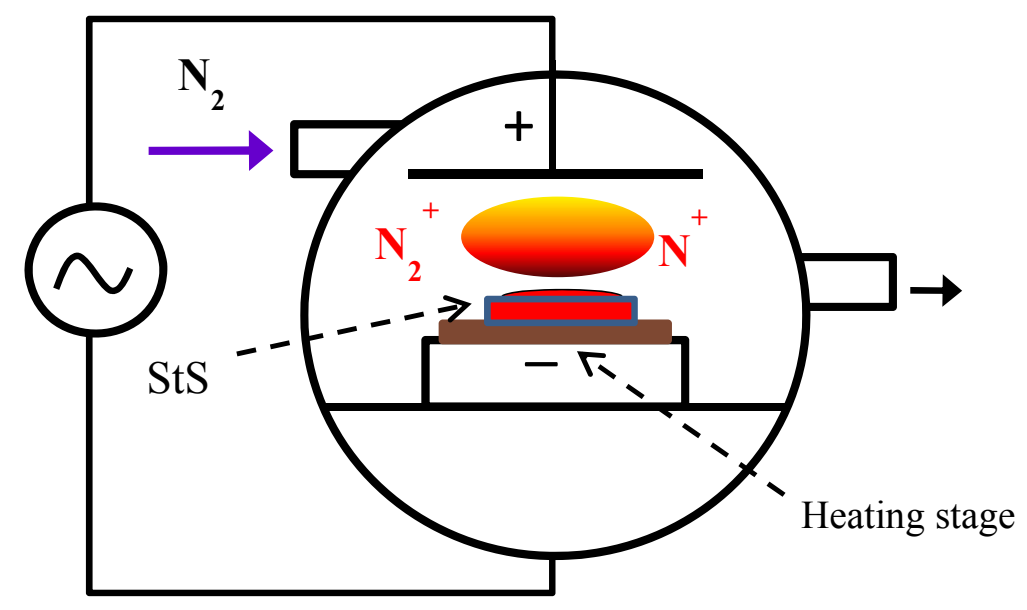

Fig. 1 Radio frequency (RF) plasma configuration for the surface treatment of StS

\section{Materials and methods}

\subsection{Materials}

A stock solution of $100 \mathrm{mg} / \mathrm{L}$ was prepared from chemicals, specifically sulfamethazine (>= $99 \%)$, tetracycline $(>=98 \%)$, and chloramphenicol $(>=98 \%)$. Working solutions were diluted from the stock solutions with distilled water.

Adsorbents were prepared using steel shavings, which were collected from steel processing workshops at University of Technology Sydney (UTS). The raw material was washed three times with distilled water, then dried at $50^{\circ} \mathrm{C}$ and ground in a pug and ring mill. The ground samples were subsequently sieved into particle sizes in the range 0-75 $\mu \mathrm{m}\left(\mathrm{M}_{3}\right)$. The particles were stored in a sealed desiccator filled with silica beads prior to experiments. For removing contaminants from the particles' surface, modified samples were subjected to plasma 
treatment in nitrogen for 15 minutes (cathode voltage $=300 \mathrm{~V}$, plasma energy $=20 \mathrm{~W}$ ). Ten grams of raw steel shavings, after being pre-treated, was evenly distributed into a clean $6 \mathrm{~cm}$ diameter glass petri dish. Following that, it was placed in the centre of the chamber of a Harrick plasma cleaner/sterilizer PDC-32G with an attached Adixen ACP 15 vacuum pump set at a pumping speed of $14 \mathrm{~m}^{3} / \mathrm{h}$. The PDC-32G was then evacuated to an ultimate total pressure of 0.3 mbar before nitrogen gas was injected into the chamber at a flow rate of 20 SCCM. The unit was then powered at the high setting (RF power of $18 \mathrm{~W}$ at $12 \mathrm{Mhz}$ ) for 10 minutes before the adsorbent was recovered $\left(\mathrm{M}_{3}-\mathrm{plN}_{2}\right)$.

\subsection{Factors affecting the removal of antibiotics}

In order to select optimal conditions for the removal process, the effects of $\mathrm{pH}$, dosage and temperature were studied. The efficiency in removing antibiotics from the aqueous solution was calculated as follows:

$$
\% \text { removal }=\frac{(C o-C e) \times 100}{C o}
$$

and the adsorption capacity was calculated using the below equation:

$$
Q e=\frac{(C o-C e) x V}{m}
$$

Where Co and $\mathrm{Ce}$ are the initial and equilibrium antibiotics concentrations $(\mathrm{mg} / \mathrm{L}), \mathrm{m}$ is the mass of StS (g) and V (L) is the volume of the antibiotics solutions.

The experiments were undertaken for 3 antibiotics (SMT, TC and CP) separately as per the following procedure:

- For investigation of the $\mathrm{pH}$ influence on the adsorption, $50 \mathrm{~mL}$ of the antibiotic solution $1000 \mu \mathrm{g} / \mathrm{L}$ were prepared into $250 \mathrm{~mL}$ flasks. The $\mathrm{pH}$ of the solutions were adjusted from 2-10 using $0.1 \mathrm{M} \mathrm{HCL}$ and $0.1 \mathrm{M} \mathrm{NaOH}$ solutions; then 0.5 gram adsorbent was added. The mixture was shaken in a shaking table at $130 \mathrm{rpm}$ for 24 
hours. The effluent was filtered through a $0.2 \mu \mathrm{m}$ filter paper. The concentrations of the compounds were then analyzed using HPLC-UV.

- Effects of adsorbent dosage $(0.1 ; 0.2 ; 0.5 ; 1 ; 2 ; 5 ; 10 ; 20 \mathrm{~g} / \mathrm{L})$ on adsorption efficiency of antibiotics on steel shavings were examined. Different amounts of adsorbent which were $0.005 ; 0.01 ; 0.025 ; 0.05 ; 0.1 ; 0.25 ; 0.5 ; 1$ gram were added to $50 \mathrm{~mL}$ solution of the antibiotic at $1000 \mu \mathrm{g} / \mathrm{L}$. The subsequent steps were carried as the same procedure as the $\mathrm{pH}$ influence tests.

- Effects of temperature to adsorption process of antibiotics on the adsorbents were carried at $20 ; 25 ; 30^{\circ} \mathrm{C}$. The volume of $50 \mathrm{~mL}$ of SMT, TC and $\mathrm{CP}$ concentrations $(100 ; 200 ; 500 ; 1000 ; 2000 ; 5000 ; 10000 ; 20000 \mu \mathrm{g} / \mathrm{L})$ were added into $250 \mathrm{~mL}$ flasks, then optimal $\mathrm{pH}$ of the solution was adjusted. The optimal amounts of adsorbent was added, then shaken at $130 \mathrm{rpm}$ in a thermostatic shaker for 24 hours.

\subsection{Kinetics and isotherms of antibiotics adsorption on StS}

The pseudo-first-order kinetic (PFO), pseudo-second-order kinetic (PSO) and intra-particle diffusion model (IDM), Langmuir and Freundlich isotherm models were used to describe the kinetics and isotherms of the adsorptive removal. The equation and linearized forms of the models are illustrated and summarized in Table 2.

Table 2 Kinetic and isotherm models of antibiotics adsorption on StS

\begin{tabular}{llc}
\hline Models & Equation & Linearized form \\
\hline Langmuir & $q_{e}=\frac{q_{\max } k_{L} C_{e}}{1+k_{L} C_{e}}$ & $\frac{C_{e}}{q_{e}}=\frac{C_{e}}{q_{\max }}+\frac{1}{k_{L} q_{\max }}$ \\
Freundlich & $q_{e}=k_{F} C_{e}{ }^{1 / n}$ & $\ln q_{e}=\ln k_{F}+\frac{1}{n} \ln C_{e}$ \\
& $\begin{array}{l}\text { Where: } \mathrm{C}_{\mathrm{e}} \text { is the equilibrium concentration }(\mathrm{mg} / \mathrm{L}) \text { of the adsorbate }(\mathrm{mg} / \mathrm{L}) . \mathrm{q}_{\mathrm{e}} \text { is adsorption } \\
\text { capacity of StS at equilibrium (mg/g). } \mathrm{q}_{\max } \text { is maximum antibiotics uptake of the adsorbent } \\
\text { (mg/g); } \mathrm{k}_{\mathrm{L}} \text { is Langmuir constant related to binding energy of adsorption }(\mathrm{L} / \mathrm{mg}) ; \mathrm{k}_{\mathrm{F}} \text { and } \mathrm{n} \text { are }\end{array}$ \\
& $\begin{array}{l}\text { Freundlich constants indicative of the adsorption capacity and adsorption intensity of the } \\
\text { adsorbent, respectively. }\end{array}$ & $\ln \left(q_{e}-q_{t}\right)=\ln q_{e}-k_{1} t$ \\
PFO & $\frac{d q_{t}}{d_{t}}=k_{1 p}\left(q_{e}-q_{t}\right)$ & \\
\hline
\end{tabular}




\begin{tabular}{lll}
\hline PSO & $\frac{d q_{t}}{d_{t}}=k_{2 p}\left(q_{e}-q_{t}\right)^{2}$ & $\frac{1}{q_{t}}=\frac{1}{k_{2} q_{e}^{2}}+\frac{1}{q_{e}}$ \\
IDM & $q_{t}=k_{i} t^{0.5}$ \\
& Where: qe amount of antibiotics adsorbed at equilibrium $(\mathrm{mg} / \mathrm{g}) ; \mathrm{qt}=$ amount of antibiotics \\
& adsorbed at time $\mathrm{t}(\mathrm{min})(\mathrm{mg} / \mathrm{g}) ; \mathrm{k}_{1 \mathrm{p}}=$ equilibrium rate constant of PFO $(1 / \mathrm{min}) ; \mathrm{k}_{2 \mathrm{p}}=$ \\
& equilibrium rate constant of PSO $(1 / \mathrm{min})$ and $\mathrm{ki}(\mathrm{mg} / \mathrm{g} \cdot \mathrm{min})=$ the rate constants of IDM, \\
& respectively.
\end{tabular}

The experiments were performed for 3 antibiotics (SMT, TC and CP) separately according to the following procedure:

- In kinetic experiments, the optimal amount of adsorbent which was obtained from the effect of adsorbent dose tests was mixed with $50 \mathrm{~mL}$ the antibiotic solution of 1000 $\mu \mathrm{g} / \mathrm{L}$ and then shaken at $130 \mathrm{rpm}$ at room temperature. The samples were taken at different times: 5, 10, 20, 30, 45, 60, 120, 240, 480, 1440 mins, filtered by PTFE filter $0.2 \mu \mathrm{m}$ and the antibiotics concentrations were analyzed.

- For examination of the isotherms, $50 \mathrm{~mL}$ solution of the antibiotic at different concentrations - 10, 50, 100, 500, 1000;2000; 5000; 10000; $20000 \mu \mathrm{g} / \mathrm{L}$ - were prepared in $250 \mathrm{~mL}$ flasks. The $\mathrm{pH}$ was adjusted to the optimum value as obtained from the $\mathrm{pH}$ effects experiments. Then the optimal amount of adsorbent which was derived from the adsorbent dose tests was added, and shaken at $130 \mathrm{rpm}$ at a fixed temperature $\left(25^{\circ} \mathrm{C}\right)$ for 24 hours. In the next step, the filtrate was filtered through a 0.2 $\mu \mathrm{m}$ PTFE filter and analyzed by HPLC-UV.

\subsection{Characterization of adsorbents}

The studied adsorbents were characterized by Zeiss Evo SEM (with attached EDS at $15 \mathrm{kV}$ ), SEM-Supra 55VP, Brunauer-Emmett-Teller (BET), X-ray photoelectron spectroscopy (XPS) and Fourier transform infrared spectroscopy (FTIR) to obtain the surface morphology, elemental composition, mineral species, surface area, porosity, and appearance of iron oxides and organic groups on the adsorbed materials.

\subsection{Analytical methods of the antibiotic concentrations}


For analyzing the concentrations of SMT, TC and $\mathrm{CP}$ in water, high performance liquid chromatography (HPLC) with detector UV was utilized. The chromatograph of antibiotics by HPLC and the analytical standard lines are depicted in Fig. 2.

The concentrations of SMT, TC and CP were analyzed by HPLC (Jasco) with auto-sampler using a reserve phase Zorbax Bonus RP C-18 column $(2.1 \times 1.5 \mathrm{~mm}, 5 \mu \mathrm{m}$ particle size, Agilent Technologies). The detection was done utilizing UV absorption at a wavelength of $285 \mathrm{~nm}$, by $50 \mu \mathrm{L}$ injection. Acetonitrile and formic acid were employed as the mobile phase A ( $\mathrm{v}: \mathrm{v}=99.9: 0.1)$ while mobile phase B consisted of Milli-Q water and formic acid ( $\mathrm{v}: \mathrm{v}=$ 99.9:0.1). The applied program of elution is presented in Table 3 and the running time of the method was $10 \mathrm{~min}$. All experiments were implemented in triplicate and data represented the average values. The deviations were less than $5 \%$.

Table 3 The elution program applied in the antibiotics analysis using HPLC

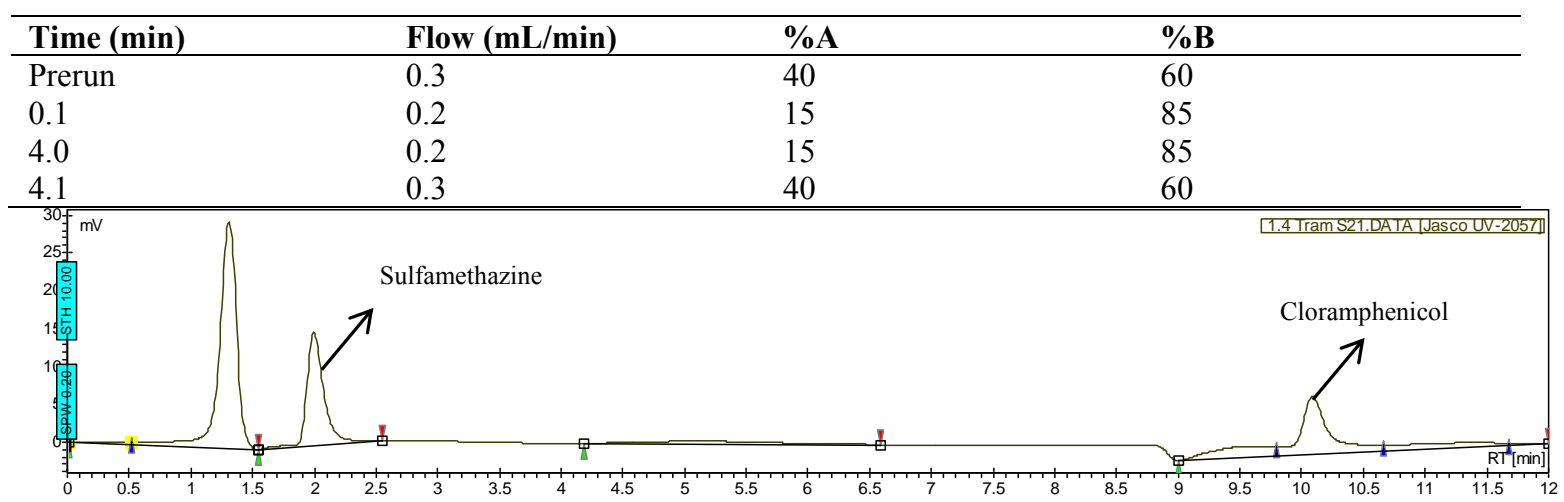



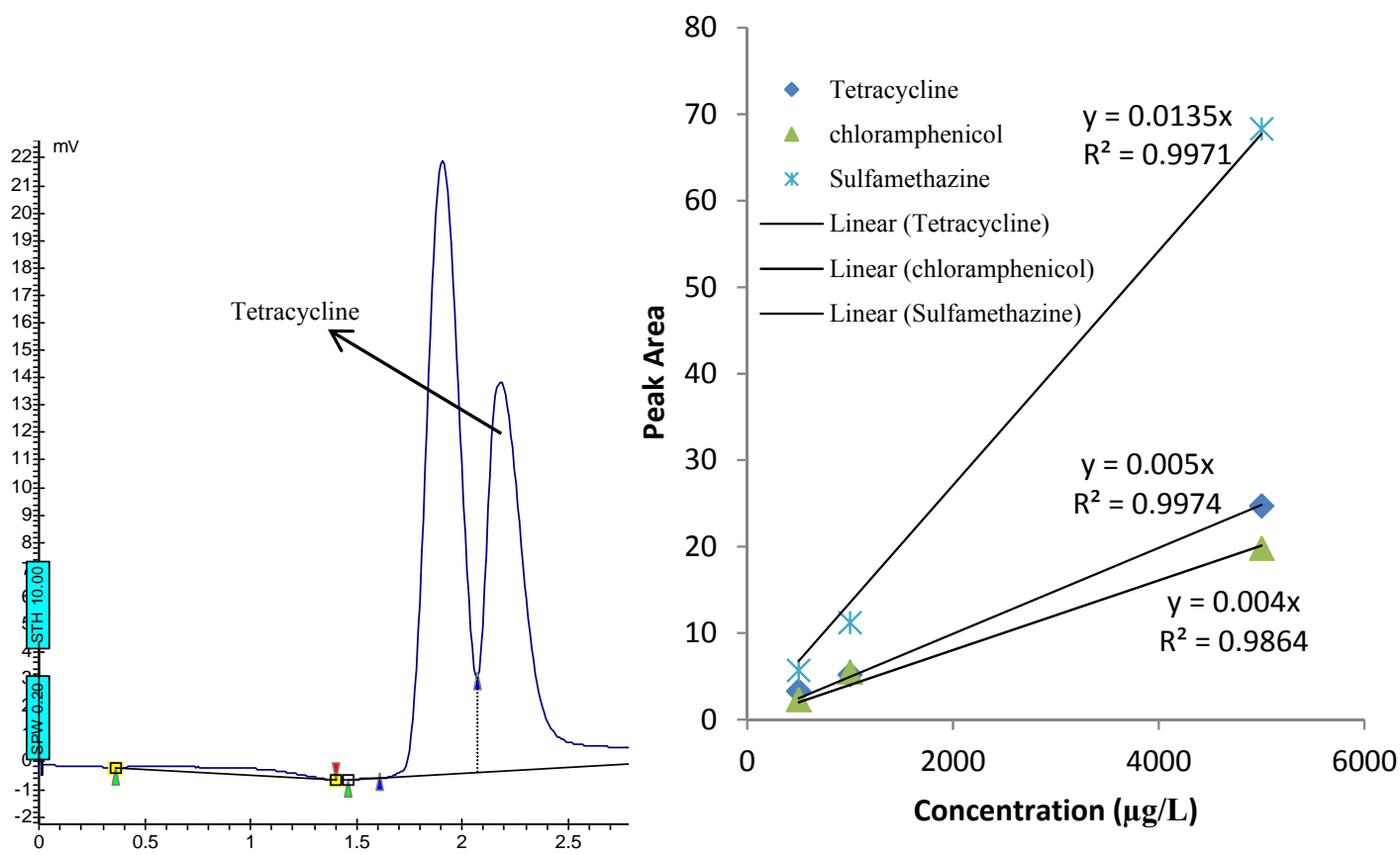

Fig. 2 (a) Chromatograph of SMT, CP and TC by HPLC- UV and (b) Analytical standard lines of SMT, TC and CP

\section{Results and discussion}

\subsection{Characterization of StS}

The SEM images indicated that the plasma treatment cleans the surface without modifying the particle morphology. From EDS outcomes, the iron content of StS increased after plasma treatment with nitrogen (from $47.7 \%$ to $55.2 \%$ ) (Table 4 and Fig. 3). Moreover, carbon and oxygen contents in $\mathrm{M}_{3}-\mathrm{plN}_{2}$ are less than that of $\mathrm{M}_{3}$. These results can be explained by the fact that plasma treatment with nitrogen removed hydrocarbon compounds and contaminants from the materials' surface. The BET results showed that the surface area of the modified plasma with nitrogen steel shavings $\left(\mathrm{M}_{3}-\mathrm{plN}_{2}\right)$ was 1.7 -fold larger than that of raw steel shavings $\left(\mathrm{M}_{3}\right)$ (Table 4). Similarly, the pore volume of the adsorbent slightly enlarged from 0.011319 to $0.01561 \mathrm{~cm}^{3} / \mathrm{g}$ (1.4-fold) after modification. The surface areas of raw and modified StS were greater than those of zero-valent iron, which was prepared from scrap iron by Rangsivek and Jekel (2005). In their study, the zero-valent iron has particle size ranged from 0.4 to $1.25 \mathrm{~mm}$, BET surface area of $0.384 \mathrm{~m}^{2} / \mathrm{g}$ and $\mathrm{Fe}^{0}$ content of $98 \%$ (Rangsivek and 
Jekel, 2005). However, the surface areas of the adsorbents were less than that of synthesized nano zero-valent iron, which had a BET surface area of $32.02 \mathrm{~m}^{2} / \mathrm{g}$ (Xia et al., 2014). In another study, the fresh scrap iron contained $81.45 \% \mathrm{Fe}, 15.56 \% \mathrm{O}$, and small amounts of $\mathrm{Al}$, Si, and Mn (Gheju and Balcu, 2011). The iron content in adsorbents of this study was less than that of scrap iron (Table 4). This outcome can explained as during steel production process an amount of carbon was added.
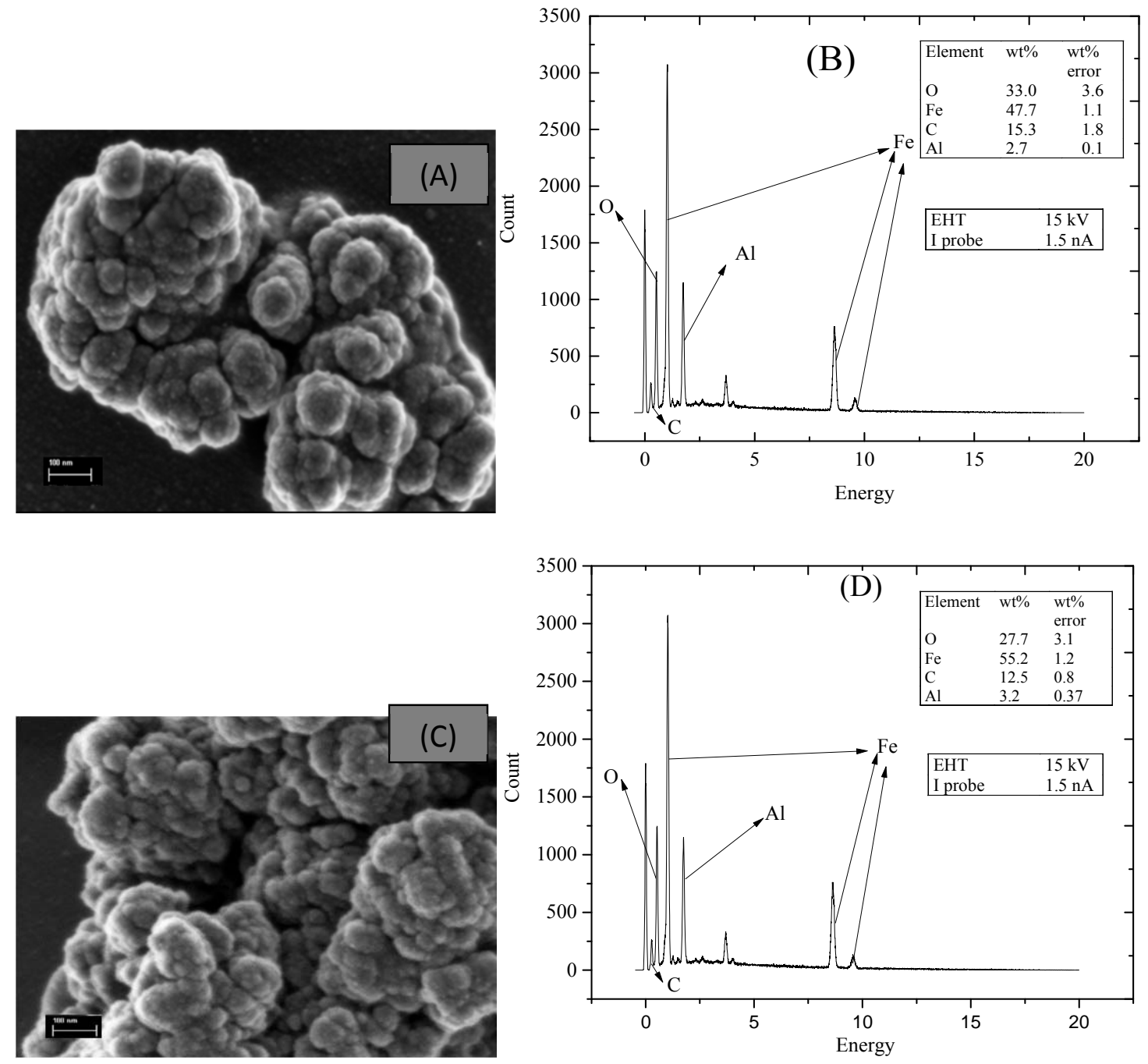

Fig. 3 SEM and EDS results of adsorbent A: SEM image of $\mathrm{M}_{3}$; B: EDS of $\mathrm{M}_{3}$; $\mathrm{C}$ : SEM image of $\mathrm{M}_{3}-$ $\mathrm{plN}_{2}$; D: EDS of $\mathrm{M}_{3}-\mathrm{plN}_{2}\left(\mathrm{M}_{3}: 0<\mathrm{StS}<75 \mu \mathrm{m} ; \mathrm{M}_{3}-\mathrm{plN}_{2}: 0<\mathrm{StS}<75 \mu \mathrm{m}\right.$ was plasma modified with $\left.\mathrm{N}_{2}\right)$

Table 4 Characterisation of the adsorbents

\begin{tabular}{|c|c|c|}
\hline Character & Raw StS $\left(\mathbf{M}_{3}\right)$ & Plasma modified StS $\left(\mathrm{M}_{3}-\mathrm{plN}_{2}\right)$ \\
\hline $\begin{array}{l}\text { Composition (\% weight) EDS } \\
\text { Surface area }\end{array}$ & $\mathrm{O} 33.0 ; \mathrm{Fe} 47.7 ; \mathrm{C} 15.3 ; \mathrm{Al} 2.7$ & $\mathrm{O} 27.7 ; \mathrm{Fe} 55.2 ; \mathrm{C} 12.5 ; \mathrm{Al} 3.2$ \\
\hline
\end{tabular}




\begin{tabular}{|c|c|c|}
\hline $\begin{array}{l}\text { Single point surface area at } \mathrm{p} / \mathrm{p}^{\circ}= \\
0.29\end{array}$ & $2.6916 \mathrm{~m}^{2} / \mathrm{g}$ & $4.2910 \mathrm{~m}^{2} / \mathrm{g}$ \\
\hline BET surface area & $2.7179 \mathrm{~m}^{2} / \mathrm{g}$ & $4.5617 \mathrm{~m}^{2} / \mathrm{g}$ \\
\hline Langmuir surface area & $4.0794 \mathrm{~m}^{2} / \mathrm{g}$ & $9.3362 \mathrm{~m}^{2} / \mathrm{g}$ \\
\hline t-Plot Micropore Area & $1.4827 \mathrm{~m}^{2} / \mathrm{g}$ & - \\
\hline t-Plot External Surface Area & $1.2351 \mathrm{~m}^{2} / \mathrm{g}$ & $5.2518 \mathrm{~m}^{2} / \mathrm{g}$ \\
\hline $\begin{array}{l}\text { Pore volume } \\
\text { Single point adsorption total pore }\end{array}$ & & \\
\hline $\begin{array}{l}\text { Single point adsorption total pore } \\
\text { volume of pores less than } 980.2 \AA \\
\text { width at } \mathrm{p} / \mathrm{p}^{\circ}=0.98\end{array}$ & $0.011319 \mathrm{~cm}^{3} / \mathrm{g}$ & $0.015610 \mathrm{~cm}^{3} / \mathrm{g}$ \\
\hline $\begin{array}{l}\text { t-Plot micropore volume } \\
\text { BJH adsorption cumulative volume }\end{array}$ & $0.000534 \mathrm{~cm}^{3} / \mathrm{g}$ & $-0.001216 \mathrm{~cm}^{3} / \mathrm{g}$ \\
\hline $\begin{array}{l}\text { of pores between } 10.000 \AA \text { and } \\
3,000.000 \AA \text { width }\end{array}$ & $0.002454 \mathrm{~cm}^{3} / \mathrm{g}$ & $0.006003 \mathrm{~cm}^{3} / \mathrm{g}$ \\
\hline Pore size & & \\
\hline $\begin{array}{l}\text { Adsorption average pore diameter } \\
\text { (4V/A by BET) }\end{array}$ & $166.5828 \AA$ & $136.8825 \AA$ \\
\hline $\begin{array}{l}\text { BJH Adsorption average pore } \\
\text { width }(4 \mathrm{~V} / \mathrm{A})\end{array}$ & $33.898 \AA$ & $40.857 \AA$ \\
\hline
\end{tabular}

Surface charge relating zeta potential values of the adsorbents depending on $\mathrm{pH}$ of solution were demonstrated in Fig. 4. The point of zero charge $\mathrm{pH}$ values $\left(\mathrm{pH}_{\mathrm{pzc}}\right)$ of $\mathrm{M}_{3}$ and $\mathrm{M}_{3}-\mathrm{plN} \mathrm{N}_{2}$ in water were defined approximately 5.5 and 5, respectively. Below this $\mathrm{pH}$ value, surface charge of the adsorbents is positive while $\mathrm{pH}$ higher than this value surface charge will become negative.

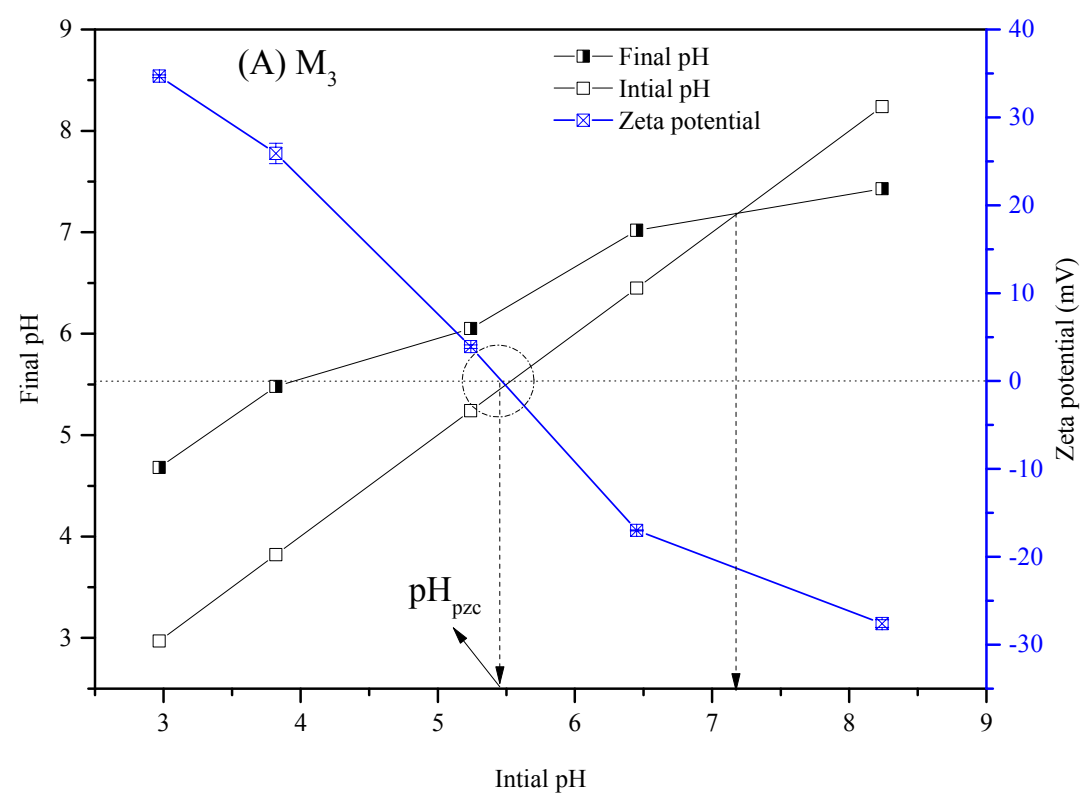




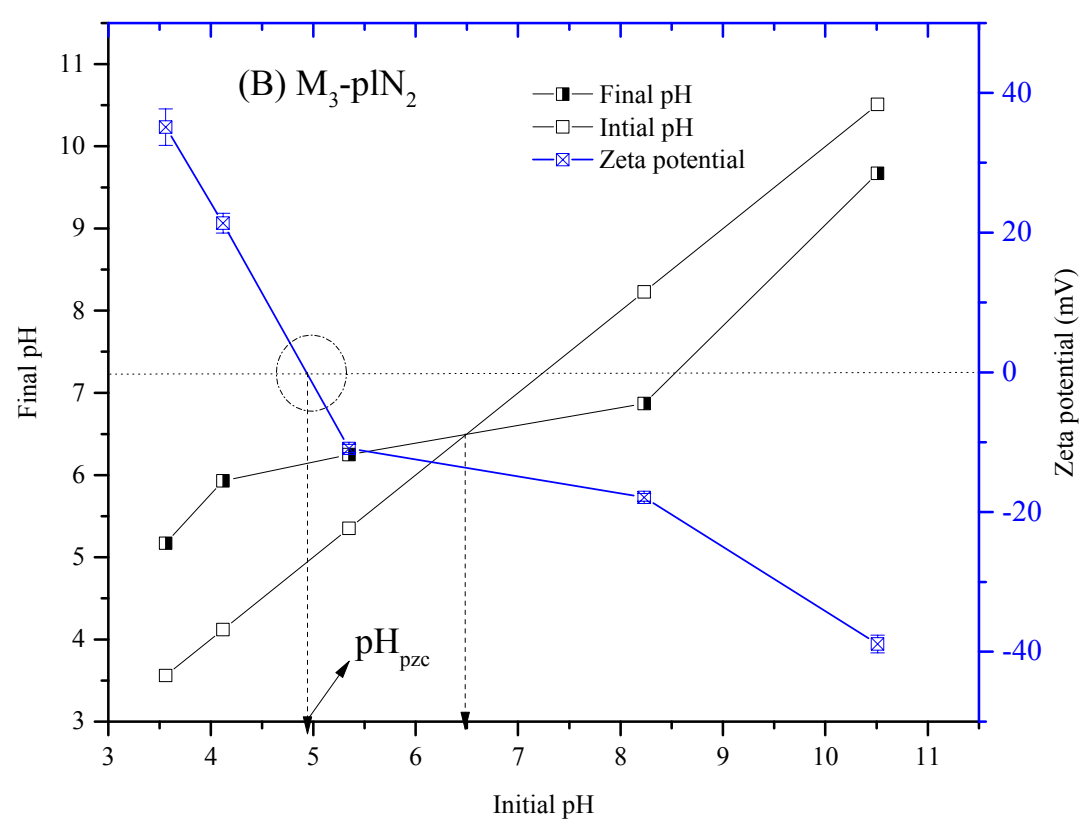

Fig. 4 Zeta potential as a function of $\mathrm{pH}$ solution: (A) $\mathrm{M}_{3}:(\mathrm{B}) \mathrm{M}_{3}-\mathrm{plN}_{2}$

\subsection{Effect of pH on removal efficiency}

The effect of $\mathrm{pH}$ on removal efficiency of antibiotics by raw steel shavings $\left(\mathrm{M}_{3}\right)$ and plasma modified steel shavings $\left(\mathrm{M}_{3}-\mathrm{plN} \mathrm{N}_{2}\right)$ are shown in Fig. 5a and 5b. Generally, pH value of the reaction solution exerts a great impact on the raw and modified steel shavings' capacity to remove antibiotics. Plasma modification has improved the absorbents' ability to remove the antibiotics.

The removal efficiency of SMT by $\mathrm{M}_{3}$ was very high in acidic solution, $\mathrm{pH} 2.5$ to 2.9 (89.3 to 93.6\%) but this fell significantly when $\mathrm{pH}$ increased from 3.8 to 9.2 (from $32.2 \%$ to $4.4 \%$ ). These changes could be attributed to the effect of $\mathrm{pH}$ on the speciation of SMT and the surface electric properties of the adsorbent. The cationic, neutral and anionic species of SMT were dominant at $\mathrm{pH}<2.5$, neutral $\mathrm{pH}$ and alkaline $\mathrm{pH}$, respectively (Qiang et al., 2013). During the ion-exchange process, the adsorbed cation $\left(\mathrm{M}^{\mathrm{n}+}\right)$ exchanges for a proton $\left(\mathrm{H}^{+}\right)$on the surface of the adsorbents as the following equation:

$($ Surface $) O H+M^{n+} \rightarrow($ Surface $) O M^{n-1}+H^{+}$ 
These results partly agreed with the study by Ahmed et al. (2017) on the removal of sulphonamide antibiotics by functionalized biochar which achieved maximum adsorption at $\mathrm{pH}$ from 3.25 to 4.5 . In contrast, the removal efficiency of SMT by MCM-48 modified magnetic nanocomposite (positive surface charge) was low at acidic $\mathrm{pH}$, rose when the $\mathrm{pH}$ increased and reached a maximum at $\mathrm{pH} 6.3$ (Qiang et al., 2013). The maximum removal efficiency of SMT by $\mathrm{M}_{3}$ reached $93.6 \%$ at $\mathrm{pH}$ 2.9. The same trend was observed for the plasma modified steel shavings' efficiency in removing SMT (Fig. 5b). The adsorbents' ability to remove SMT declined when the $\mathrm{pH}$ level increased. The sorption process reached a maximum at $\mathrm{pH} 3.01$ with a removal efficiency of $95.3 \%$.

The adsorption of $\mathrm{TC}$ on $\mathrm{M}_{3}$ and $\mathrm{M}_{3}$-plN 2 were also $\mathrm{pH}$-dependent processes. The removal efficiency of $\mathrm{TC}$ by $\mathrm{M}_{3}$ improved when $\mathrm{pH}$ increased from 2.4 to 5.1, then fell away with a decrease in $\mathrm{pH}$ from 6.8 to 8.3 . The adsorption maximum reached a value of $68.1 \%$ of TC at $\mathrm{pH}$ 5.1. The removal efficiency of $\mathrm{TC}$ by $\mathrm{M}_{3}-\mathrm{plN} \mathrm{N}_{2}$ was higher than that by $\mathrm{M}_{3}$ with the maximum adsorption efficiency of $82.1 \%$ at $\mathrm{pH} 4.7$. The experimental results displayed that adsorptions of $\mathrm{TC}$ on the adsorbents were effective in both acidic and neutral $\mathrm{pH}$. These findings could be due to the fact that similar to SMT, TC exists in cationic, zwitterionic and anionic forms under acidic, moderately acidic to neutral and alkaline conditions (Chen et al., 2011). When $\mathrm{pH}>7$ or an alkaline condition creates repulsion at the surface of the adsorbate and the adsorbent, this results in poor removal efficiency.

Compared to the sorptions of SMT and TC, the sorptions of $\mathrm{CP}$ on $\mathrm{M}_{3}$ and $\mathrm{M}_{3}-\mathrm{plN}_{2}$ were more stable regarding $\mathrm{pH}$ changes (Fig. 5). Variation in $\mathrm{pH}$ values did not significantly change the efficiency of CP degradation. These outcomes could be explained as CP is a nonionisable compound thus changes in $\mathrm{pH}$ did not lead to changes in removal efficiencies. However, the results indicated that $\mathrm{CP}$ was also most effectively removed by the adsorbent at low $\mathrm{pH}$ values. From $\mathrm{pH} 3-3.8, \mathrm{CP}$ in the solution was completely removed by the adsorbents 
and maximum removal efficiencies were obtained (100\%). The adsorption of CP slightly reduced at neutral and alkaline $\mathrm{pH}$ values and reached its lowest at $\mathrm{pH} 7.9$ with $\mathrm{M}_{3}(86.4 \%)$ and $\mathrm{pH} 6.3$ with $\mathrm{M}_{3}-\mathrm{plN}_{2}(87.1 \%)$. These outcomes were similar to a previous report using persulfate activated by $\mathrm{Fe}^{2+}$ and zero-valent iron for removing $\mathrm{CP}$ from aqueous solution (Nie et al., 2015).

Of the three antibiotics, most $\mathrm{CP}$ was removed by $\mathrm{M}_{3}$ and $\mathrm{M}_{3}-\mathrm{plN}_{2}$ and removal efficiency remained moderately stable with observed changes in $\mathrm{pH}$ (maximum at $\mathrm{pH} 3$ ) while the process of removing SMT and TC were less efficient and largely depended on $\mathrm{pH}$ value. The adsorbents best adsorbed SMT and TC when the antibiotics exist in their neutral species. These results were demonstrated by the $\mathrm{pH}$ values of solution at which SMT was most efficiently removed at pH3 while the highest adsorption of TC was achieved at pH5 (Fig.5).

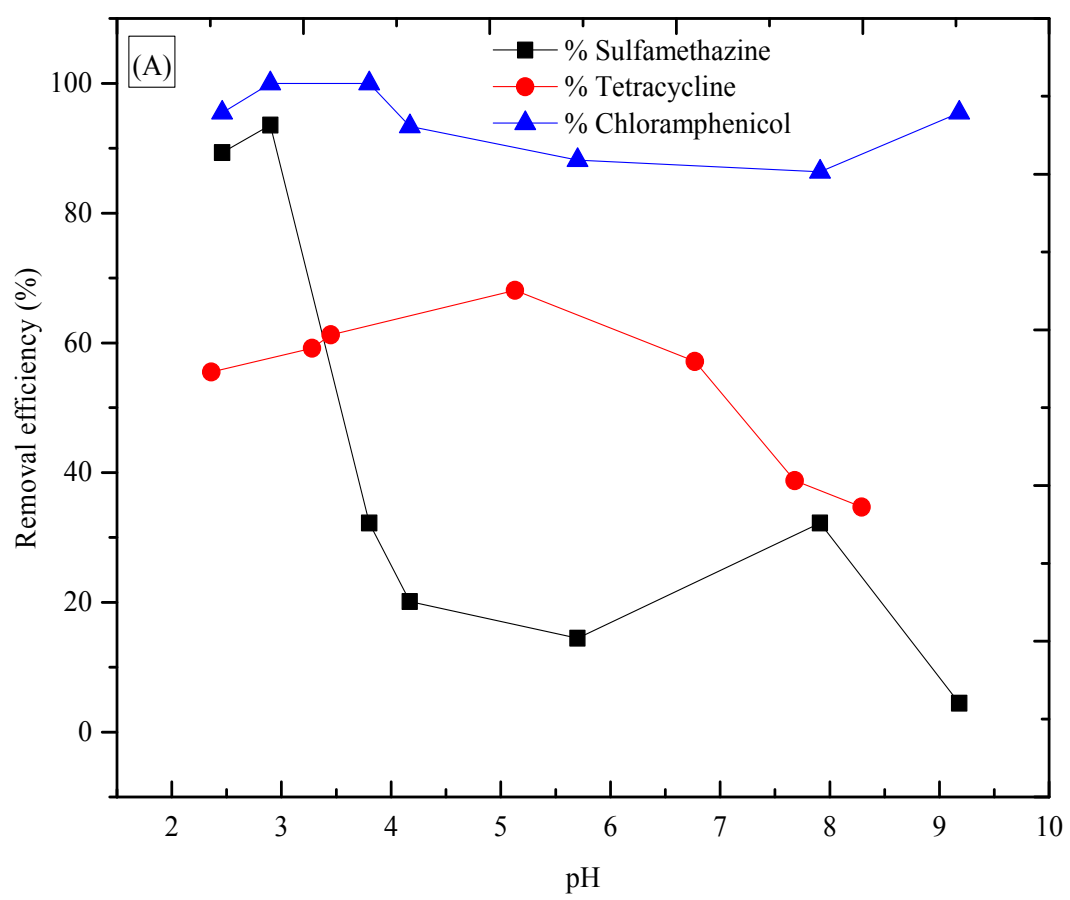




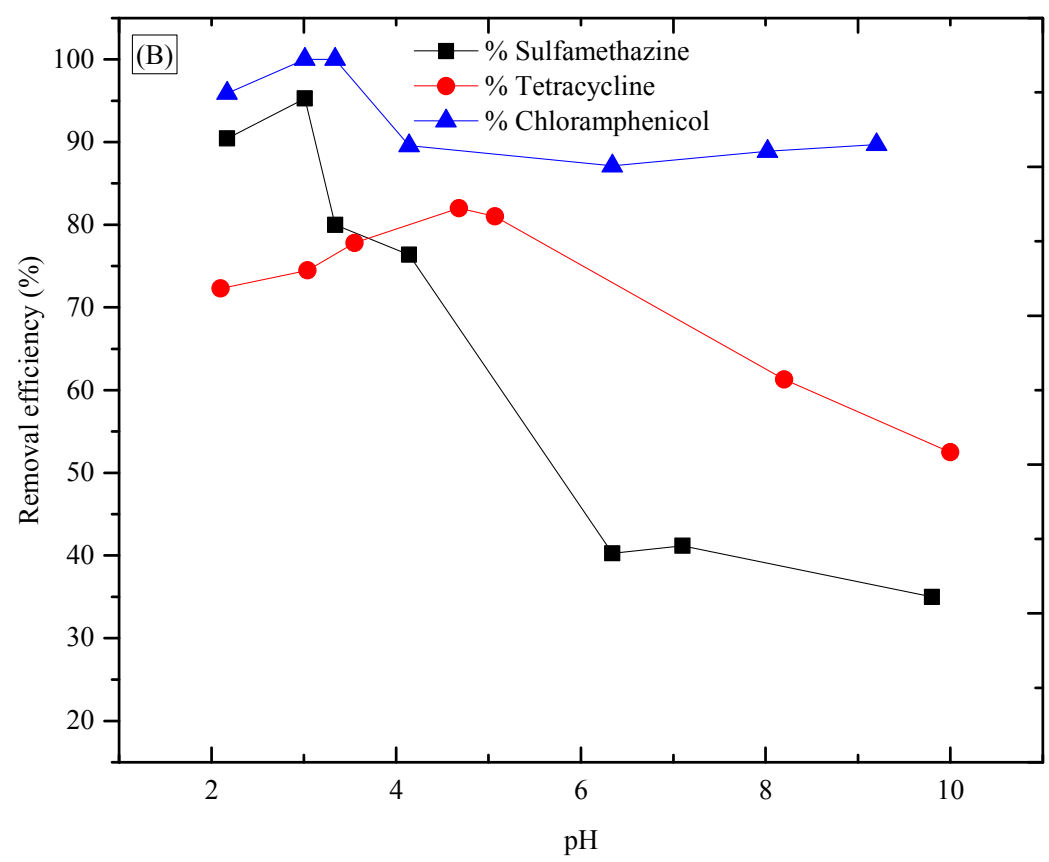

Fig. 5 Effect of $\mathrm{pH}$ on adsorption of the antibiotics on (A) $\mathrm{M}_{3}$; (B) $\mathrm{M}_{3}-\mathrm{plN}_{2}$

\subsection{The dosage effect}

For the selection of adsorbent dose, different doses of adsorbent used were $0.1 ; 0.2 ; 0.5 ; 1 ; 2$;

$5 ; 10 ; 20 \mathrm{~g} / \mathrm{L}$ in order to compare removal efficiencies of antibiotics by $\mathrm{M}_{3}$ and $\mathrm{M}_{3}-\mathrm{plN}_{2}$. The results in Fig. 6 reveal that the removal efficiency of the antibiotics improved when accompanied by an increase in doses. This improvement was a result of the catalytic reduction happening on the surface of the materials for adsorption and reaction sites (Xia et al., 2014). The maximum adsorption processes of antibiotics on both $\mathrm{M}_{3}$ and $\mathrm{M}_{3}-\mathrm{plN} \mathrm{N}_{2}$ were reached at a dose of $2 \mathrm{~g} / \mathrm{L}$. Using a dose of $2 \mathrm{~g} / \mathrm{L}$, the removal efficiencies of SMT, TC and CP by $\mathrm{M}_{3}$ and $\mathrm{M}_{3}-\mathrm{plN} \mathrm{N}_{2}$ were $40.6 ; 67.8 ; 91.4 \%$ and $48.9 ; 68.4 ; 95.5 \%$, respectively. In the study by Xia et al. (2014), at the dose of $1.06 \mathrm{~g} / \mathrm{L}$ of adsorbent, initial $\mathrm{pH} 6.8$ and air presence, CP (100 mg/L) was totally removed by nano zero-valent iron within $5 \mathrm{~min}$. 

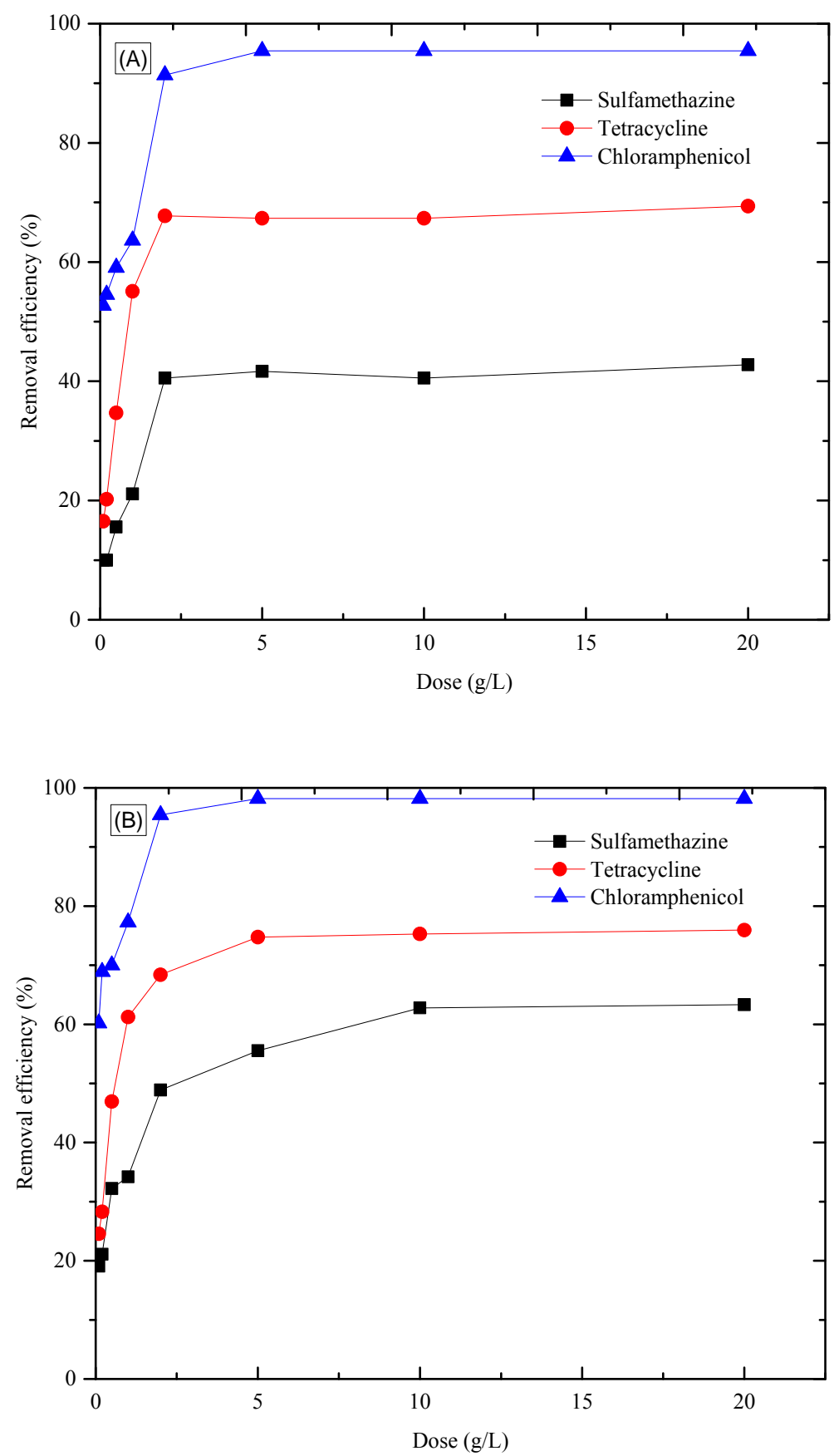

Fig. 6 Effect of dose on antibiotics adsorption efficiency using (A) $\mathrm{M}_{3}$; (B) $\mathrm{M}_{3}-\mathrm{plN}_{2}$

\subsection{Temperature/thermodynamic}

The thermodynamic parameters for the adsorption of antibiotics onto $M_{3}$ and $\mathrm{M}_{3}-\mathrm{plN} \mathrm{N}_{2}$ were calculated from experimental data, using Van't Hoff and Arrhenius equations (Boparai et al., 2011): 
$\Delta \mathrm{G}^{\mathrm{o}}=-\mathrm{RT} \ln \mathrm{K}_{\mathrm{d}}($ Eq.1)

$\operatorname{LnKd}=\frac{-\Delta \mathrm{H}^{o}}{R T}+\frac{\Delta \mathrm{S}^{o}}{R}($ Eq. 2$)$

where $K_{d}$ is the distribution coefficient of the adsorption process; $\Delta \mathrm{G}^{\circ}, \Delta \mathrm{H}^{\circ}$, and $\Delta \mathrm{S}^{\circ}$ are the changes in Gibbs free energy $(\mathrm{J} / \mathrm{mol})$, enthalpy $(\mathrm{J} / \mathrm{mol})$ and entropy $(\mathrm{J} / \mathrm{mol} / \mathrm{K})$, respectively; $\mathrm{T}$ is the absolute temperature $(\mathrm{K})$; and $\mathrm{R}$ is the gas constant $(8.314 \mathrm{~J} / \mathrm{mol} / \mathrm{K})$.

$\mathrm{K}_{\mathrm{d}}$ at a specific temperature was defined by plotting $\ln (\mathrm{qe} / \mathrm{Ce})$ versus qe, using linear regression type. The value of $\mathrm{K}_{\mathrm{d}}$ was represented by the intercept of the plot (Boparai et al., 2011). Then, $\Delta G^{\circ}$ was obtained by the Eq. 1 . Finally, $\ln K_{d}$ was plotted against $1 / T$ to calculate $\Delta \mathrm{H}^{\circ}$ and $\Delta \mathrm{S}^{\circ}$ from the slope and intercept of the plot, respectively using Eq.2.

From the experimental results, the adsorption of SMT, TC and CP were best at $25^{\circ} \mathrm{C}$ among the studied temperature range from 20 to $30^{\circ} \mathrm{C}$. Adsorption capacities rose significantly from 20 to $25^{\circ} \mathrm{C}$. A further increase of temperature from 25 to $30^{\circ} \mathrm{C}$ decreased the adsorption capacity. Table 5 illustrates the thermodynamic parameters for antibiotics removal by $\mathrm{M}_{3}$ and $\mathrm{M}_{3}-\mathrm{plN} \mathrm{N}_{2}$. The negative values of $\Delta \mathrm{G}^{\circ}$ indicated that the adsorption of SMT, TC and CP on $\mathrm{M}_{3}$ and $\mathrm{M}_{3}-\mathrm{plN}_{2}$ are spontaneous in nature. The $\Delta \mathrm{G}^{\circ}$ values reduced with the rose of temperature from 20 to $25^{\circ} \mathrm{C}$ and increased from 25 to $30^{\circ} \mathrm{C}$, demonstrating at $25^{\circ} \mathrm{C}$ the adsorption process most effectively occurred. The similar results were achieved with changes of the adsorption capacities at different temperatures and can be ascribed to the activation of adsorbents by the temperature. In detail, temperature rise from 21 to $25^{\circ} \mathrm{C}$ is needed to overcome activation energy, but further rise above $25^{\circ} \mathrm{C}$ triggered a reduction of adsorption which releases heat. That is probably explained by the complex relation between chemical activation energy and exothermic reaction nature of adsorption (Ahmed et al., 2017). The $\Delta \mathrm{H}^{\circ}$ values of SMT and TC adsorption were positive, while a negative $\Delta \mathrm{H}^{\circ}$ of the $\mathrm{CP}$ adsorption was achieved. These results specified that the adsorption of SMT and TC was 
endothermic in nature whereas exothermic was the nature of CP adsorption (Nguyen et al., 2014). The outcomes in Table 5 show that the values of $\Delta S^{\circ}$ in most cases of antibiotics elimination by the adsorbents were positive. According to Sengil and Özacar (2008), the results discovered high affinity of adsorbents for most cases of antibiotics adsorption on $\mathrm{M}_{3}$ and $\mathrm{M}_{3}-\mathrm{plN}_{2}$ and an increased randomness between solid-solution interfaces during the removal process.

Table 5 Thermodynamic parameters for antibiotics adsorption on $\mathrm{M}_{3}$ and $\mathrm{M}_{3}-\mathrm{plN}_{2}$

\begin{tabular}{|c|c|c|c|c|c|c|c|}
\hline $\begin{array}{c}\text { Adsorbent/ } \\
\text { Antibiotic }\end{array}$ & $\begin{array}{c}\text { Temperature } \\
\left({ }^{\circ} \mathrm{C}\right)\end{array}$ & $\begin{array}{c}\text { Qmax } \\
\text { exp. } \\
(\mu \mathrm{g} / \mathrm{g})\end{array}$ & Kd & $\begin{array}{c}\Delta \mathbf{G}^{\mathbf{0}} \\
\left(\mathrm{J} / \mathbf{m o l}^{\prime}\right)\end{array}$ & $\begin{array}{c}\Delta \mathbf{H}^{\mathbf{0}} \\
\left(\mathrm{J} / \mathrm{mol}^{\prime}\right)\end{array}$ & $\begin{array}{c}\Delta \mathrm{S}^{\mathbf{0}} \\
(\mathrm{J} / \mathrm{mol} / \mathrm{K})\end{array}$ & $\mathbf{r}^{2}$ \\
\hline \multicolumn{8}{|l|}{$\mathbf{M}_{3}$} \\
\hline \multirow{4}{*}{ SMT } & 20 & 1512 & 8.715 & -5274 & & & \\
\hline & 25 & 2590 & 8.987 & -5440 & 1436 & 23 & 0.394 \\
\hline & 30 & 1555 & 8.884 & -5503 & & & \\
\hline & 20 & 988 & 4.143 & -3463 & & & \\
\hline \multirow[t]{3}{*}{$\mathrm{TC}$} & 25 & 1549 & 6.003 & -4440 & 3565 & 25 & 0.014 \\
\hline & 30 & 1084 & 4.331 & -3693 & & & \\
\hline & 20 & 1874 & 8.876 & -5319 & & & \\
\hline \multirow[t]{2}{*}{$\mathrm{CP}$} & 25 & 2920 & 9.043 & -5456 & -7494 & -7 & 0.607 \\
\hline & 30 & 2009 & 8.012 & -5242 & & & \\
\hline \multicolumn{8}{|l|}{$M_{3}-p l N_{2}$} \\
\hline & 20 & 1972 & 5.765 & -4263 & & & \\
\hline \multirow{3}{*}{ SMT } & 25 & 2747 & 9.209 & -5501 & 8302 & 44 & 0.053 \\
\hline & 30 & 2065 & 6.421 & -4685 & & & \\
\hline & 20 & 1015 & 4.654 & -3746 & & & \\
\hline \multirow[t]{3}{*}{$\mathrm{TC}$} & 25 & 1988 & 7.422 & -4966 & 9924 & 48 & 0.078 \\
\hline & 30 & 1281 & 5.300 & -4201 & & & \\
\hline & 20 & 2336 & 8.904 & -5326 & & & \\
\hline \multirow[t]{2}{*}{$\mathrm{CP}$} & 25 & 4018 & 9.147 & -5484 & -667 & 16 & 0.058 \\
\hline & 30 & 2801 & 8.821 & -5485 & & & \\
\hline
\end{tabular}

\subsection{Modeling of sorption isotherms}

Sorption isotherm plots and isotherm parameters of Langmuir and Freundlich isotherm models are presented and summarized in Fig. 7, Table 2 and Table 6. Adsorption capacities of antibiotics increased when the initial concentrations rose. Table 6 shows that the sorption data for the antibiotics favored both the Langmuir and Freundlich isotherm models. Yet they slightly better fitted with the Langmuir model where good regressions $\left(0.923 \leq \mathrm{r}^{2} \leq 0.985\right)$ were observed. Maximum Langmuir adsorption capacities ( $\mathrm{Q}_{\max )}$ of SMT, TC, CP on $\mathrm{M}_{3}$ and $\mathrm{M}_{3}$ - 
plN ${ }_{2}$ were: $2519.98 ; 2702.55 ; 1720.20 ; 2158.36 ; 2772.81$ and $2920.11 \mu \mathrm{g} / \mathrm{g}$, respectively. The order of the antibiotics' sorption affinity on the adsorbents can be shown as follows: $\mathrm{CP}>\mathrm{SMT}>\mathrm{TC}$. On the other hand, maximum adsorption constant $\left(\mathrm{K}_{\mathrm{F}}\right)$ values following Freundlich isotherm with smaller $\mathrm{r}^{2}$ values were: $741.81 ; 851.17 ; 101.58 ; 183.67 ; 920.30$; 944.14 $\mu \mathrm{g}^{1-\mathrm{n}} \mathrm{L}^{\mathrm{n}} \mathrm{g}^{-1}$, respectively, for SMT, TC, CP on $\mathrm{M}_{3}$ and $\mathrm{M}_{3}-\mathrm{plN}_{2}$.

The observed $\mathrm{K}_{\mathrm{F}}$ values were higher than reported values in other studies using different adsorbents for removing SMT, TC and CP. For instance, nano zero-valent iron was found to indicate maximum Freundlich SMT adsorption capacities of $8.08 ; 7.03 ; 6.11 \mu \mathrm{g}^{1-\mathrm{n}} \mathrm{L}^{\mathrm{n}} \mathrm{g}^{-1}$, respectively, at 288; 298; $308 \mathrm{~K}$ (Qiang et al., 2013). Additionally, bamboo charcoal prepared by Liao et al. (2013) exhibited the $\mathrm{K}_{\mathrm{F}}$ constants of $0.76 ; 0.04 \mathrm{mg}^{1-\mathrm{n}} \mathrm{L}^{\mathrm{n}} \mathrm{g}^{-1}$ in the removal of TC and respectively.

\subsection{Modeling of sorption kinetics}

The kinetics of SMT, TC, and CP sorption on $\mathrm{M}_{3}$ and $\mathrm{M}_{3}-\mathrm{plN}_{2}$ were fitted to PFO, PSO and IDM models as presented in Table 2, Table 6 and Fig. 8. Depending on the correlation coefficient $\left(\mathrm{r}^{2}\right)$ and $\mathrm{Q}_{\mathrm{e}}$ cal adsorption capacity at equilibrium was calculated following kinetic equation values, the sorption kinetics of the antibiotics on the adsorbents was well fitted with PFO and PSO (high $\mathrm{r}^{2}$ ) while the data was not fitted to the IDM model (at very low $\mathrm{r}^{2}$ ). The values of PFO rate constant $\mathrm{k}_{1 \mathrm{p}}$ and PSO rate constant $\mathrm{k}_{2 \mathrm{p}}$ decreased as $\mathrm{SMT}-\mathrm{M}_{3}>\mathrm{SMT}-\mathrm{M}_{3}-$

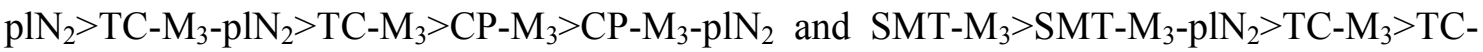
$\mathrm{M}_{3}-\mathrm{plN}_{2}>\mathrm{CP}-\mathrm{M}_{3}>\mathrm{CP}-\mathrm{M}_{3}-\mathrm{plN} \mathrm{pl}_{2}$, respectively. The antibiotics were adsorbed significantly in the first $30 \mathrm{~min}$ then reduced and reached equilibrium at $60 \mathrm{~min}$. This equilibrium time is the same as that in another study using polyvinylpyrrolidone modified nanoscale zero-valent iron to remove TC (1 hour) (Chen et al., 2011). It is also quicker than the time documented in one report utilizing MCM-48 modified magnetic mesoporous nanocomposite (24 hours) (Qiang et al., 2013). Maximum sorption constants (Qe cal) of SMT, TC, CP on $\mathrm{M}_{3}$ and $\mathrm{M}_{3}-\mathrm{pl} \mathrm{N}_{2}$ 
following the PFO model of $212.81 ; 290.38 ; 369.74 ; 417.01 ; 370.16 ; 445.09 \mu \mathrm{g} / \mathrm{g}$, correspondingly, while the PSO adsorption capacities (Qe cal) were 218.16; 299.95; 384.15; $434.97 ; 391.81 ; 470.1 \mu \mathrm{g} / \mathrm{g}$, correspondingly. 


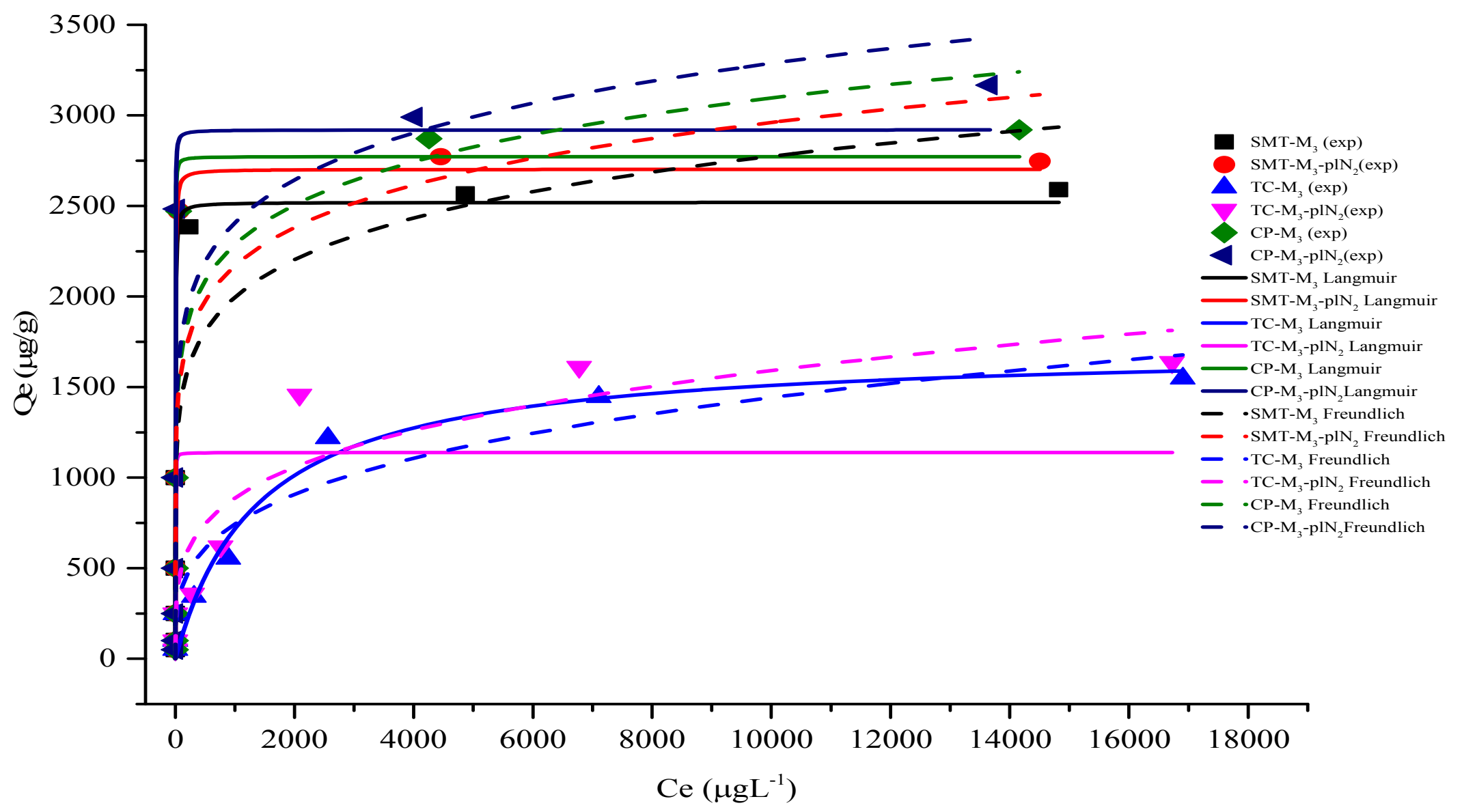

2 Fig. 7 Langmuir and Freundlich adsorption of SMT, TC, $\mathrm{CP}$ on $\mathrm{M}_{3}$ and $\mathrm{M}_{3}$-plN $\mathrm{N}_{2}$ (initial concentration: 100 - $20000 \mu \mathrm{g} / \mathrm{L}$; pH 3 was adjusted for SMT, $\mathrm{CP}$; pH

35 for TC; adsorbent dose of $2 \mathrm{~g} / \mathrm{L}$; at $25^{\circ} \mathrm{C}$ ) 


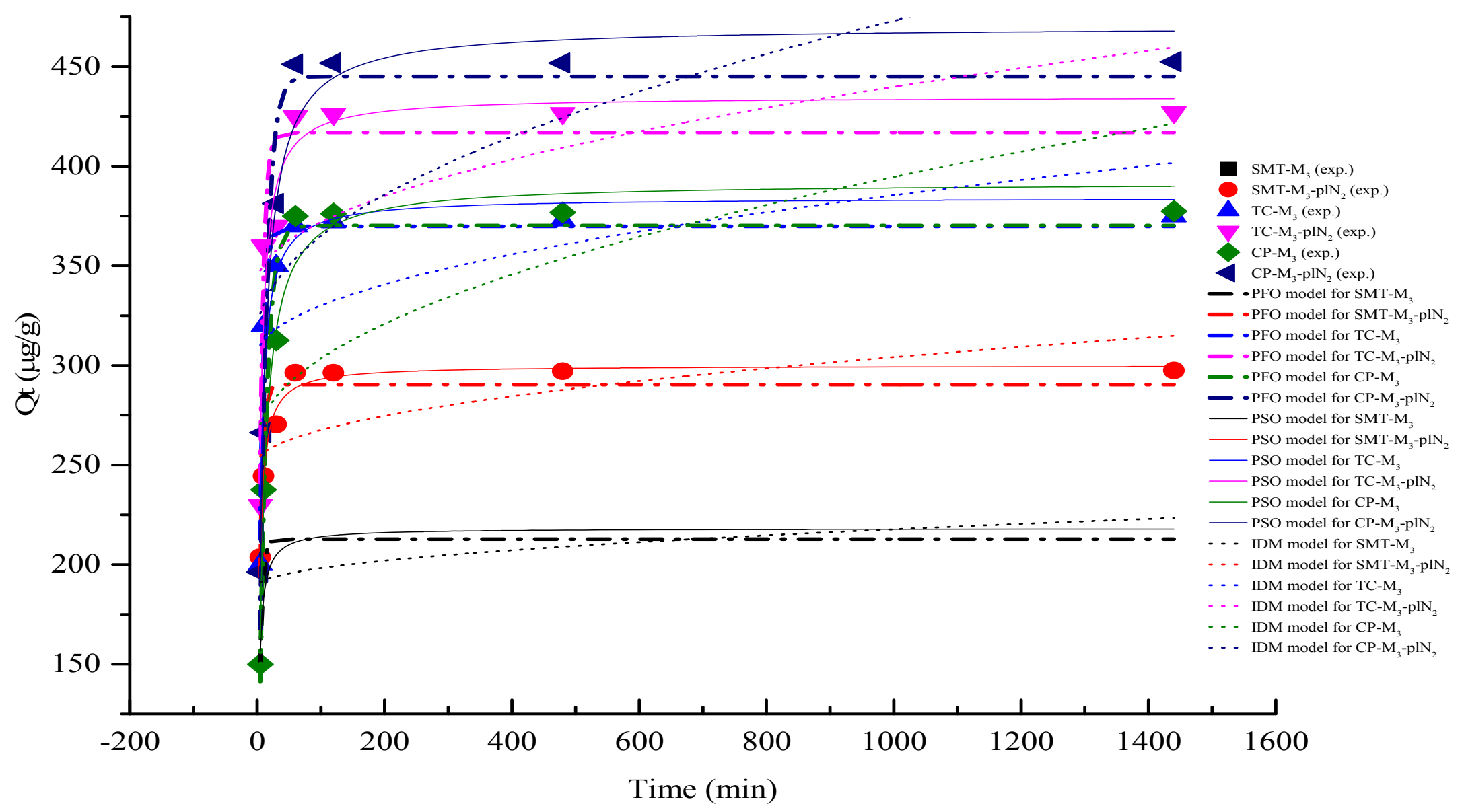

2

3 Fig. 8 Sorption kinetics of SMT, TC and $\mathrm{CP}$ on $\mathrm{M}_{3}$ and $\mathrm{M}_{3}-\mathrm{plN}_{2}$ (initial concentration: $1000 \mu \mathrm{g} / \mathrm{L}$; no $\mathrm{pH}$ adjustment; adsorbent dose of 2g/L; at room

4 temperature) 
1 Table 6 Isotherm and kinetic parameters using the non-linear regression method for antibiotics adsorption onto $\mathrm{M}_{3}$ and $\mathrm{M}_{3}-\mathrm{plN}_{2}$

\begin{tabular}{|c|c|c|c|c|c|c|c|c|c|c|c|c|c|}
\hline \multirow{2}{*}{$\begin{array}{l}\text { Isotherm } \\
\text { parameters }\end{array}$} & \multicolumn{6}{|c|}{ Antibiotic/adsorbent } & \multirow{2}{*}{ Kinetic parameters } & \multicolumn{6}{|c|}{ Antibiotic/adsorbent } \\
\hline & $\begin{array}{l}\text { SMT- } \\
\mathrm{M}_{3}\end{array}$ & $\begin{array}{l}\text { SMT- } \\
\mathrm{M}_{3}-\mathrm{plN}_{2}\end{array}$ & $\begin{array}{l}\mathrm{TC}- \\
\mathrm{M}_{3}\end{array}$ & $\begin{array}{l}\text { TC- } \\
\mathrm{M}_{3-} \\
\mathrm{plN}_{2}\end{array}$ & $\begin{array}{l}\mathrm{CP}- \\
\mathrm{M}_{3}\end{array}$ & $\begin{array}{l}\mathrm{CP}- \\
\mathrm{M}_{3}^{-} \\
\mathrm{plN}_{2}\end{array}$ & & $\begin{array}{l}\text { SMT- } \\
\mathrm{M}_{3}\end{array}$ & $\begin{array}{l}\text { SMT- } \\
\mathrm{M}_{3}-\mathrm{plN}_{2}\end{array}$ & $\mathrm{TC}-\mathrm{M}_{3}$ & $\begin{array}{l}\text { TC- } \mathrm{M}_{3}- \\
\mathrm{plN}_{2}\end{array}$ & $\begin{array}{l}\mathrm{CP}- \\
\mathrm{M}_{3}\end{array}$ & $\begin{array}{l}\mathrm{CP}-\mathrm{M}_{3}- \\
\mathrm{plN}_{2}\end{array}$ \\
\hline 1. Langmuir & & & & & & & 1. Pseudo-first-order & & & & & & \\
\hline $\begin{array}{l}\text { Qmax exp. } \\
(\mu \mathrm{g} / \mathrm{g})\end{array}$ & 2590.1 & 2746.5 & 1548.5 & 1987.5 & 2920.1 & 3167.5 & Qe $\exp (\mu \mathrm{g} / \mathrm{g})$ & 213.3 & 297.4 & 375.1 & 427.2 & 377.5 & 452.5 \\
\hline $\begin{array}{l}\text { Qmax cal. } \\
(\mu \mathrm{g} / \mathrm{g})\end{array}$ & 2519.98 & 2702.55 & $\begin{array}{l}1720.2 \\
0\end{array}$ & $\begin{array}{l}2158.3 \\
6\end{array}$ & $\begin{array}{l}2772.8 \\
1\end{array}$ & $\begin{array}{l}2920.1 \\
1\end{array}$ & Qe cal $(\mu \mathrm{g} / \mathrm{g})$ & 212.81 & 290.38 & 369.74 & 417.01 & $\begin{array}{l}370.1 \\
6\end{array}$ & 445.09 \\
\hline $\mathrm{K}_{\mathrm{L}}$ & 0.340 & 0.374 & $\begin{array}{l}7.1440 \\
7 \times 10^{-4}\end{array}$ & 0.001 & $\begin{array}{l}1.1102 \\
7\end{array}$ & 0.86 & $\mathrm{~K}_{1} \mathrm{p}\left(\mathrm{min}^{-1}\right)$ & 0.2374 & 0.22055 & 0.17143 & 0.17252 & $\begin{array}{l}0.096 \\
17\end{array}$ & 0.09467 \\
\hline 2. Freundlich & 0.985 & 0.982 & 0.958 & 0.952 & 0.981 & 0.923 & $\begin{array}{l}\mathrm{r}^{2} \\
\text { 2. Pseudo-second- } \\
\text { order }\end{array}$ & 0.999 & 0.872 & 0.960 & 0.895 & 0.958 & 0.956 \\
\hline $\mathrm{K}_{\mathrm{F}}$ & 741.81 & 851.17 & 101.58 & 183.67 & 920.30 & 944.14 & Qe cal $(\mu \mathrm{g} / \mathrm{g})$ & 218.16 & 299.95 & 384.15 & 434.97 & $\begin{array}{l}391.8 \\
1\end{array}$ & 470.1 \\
\hline $\mathrm{n}$ & 6.9821 & 7.3873 & 3.4716 & 3.9235 & 7.5920 & 7.3824 & $\mathrm{~K}_{2} \mathrm{p}\left(\min ^{-1}\right)$ & 0.00234 & 0.00142 & $\begin{array}{l}7.66713 x \\
10^{-4}\end{array}$ & $\begin{array}{l}6.55977 \\
\times 10^{-4}\end{array}$ & $\begin{array}{l}3.649 \\
6 \times 10^{-4}\end{array}$ & $\begin{array}{l}3.06411 \\
\times 10^{-4}\end{array}$ \\
\hline \multirow[t]{4}{*}{$r^{2}$} & 0.864 & 0.820 & 0.926 & 0.910 & 0.843 & 0.833 & 3. IDM & 0.913 & 0.980 & 0.894 & 0.895 & 0.972 & 0.974 \\
\hline & & & & & & & $\mathrm{Kp}\left(\mathrm{mg} \cdot \mathrm{g}^{-1} \cdot \mathrm{min}^{-1}\right)$ & 0.90235 & 1.69429 & 2.56189 & 3.13608 & $\begin{array}{l}4.217 \\
17\end{array}$ & 5.00113 \\
\hline & & & & & & & $\mathrm{C}$ & 189.16 & 250.58 & 304.41 & 340.59 & $\begin{array}{l}261.2 \\
1\end{array}$ & 314.86 \\
\hline & & & & & & & $r^{2}$ & 0.075 & 0.238 & 0.125 & 0.175 & 0.242 & 0.247 \\
\hline
\end{tabular}

2 


\subsection{Before and after adsorption characterisation of adsorbents}

To generate insights on the adsorption of antibiotics from aqueous solution by the adsorbents, FTIR and XPS was employed. FTIR spectra of the adsorbents before and after adsorption including $\mathrm{M}_{3}, \mathrm{M}_{3}-\mathrm{plN} \mathrm{N}_{2}$, SMT loaded $\mathrm{M}_{3}-\mathrm{plN}_{2}$, TC loaded $\mathrm{M}_{3}-\mathrm{plN}_{2}$, CP loaded $\mathrm{M}_{3}-\mathrm{plN}_{2}$ and mixed antibiotics (SMT, TC and CP) loaded $\mathrm{M}_{3}-$ plN 2 were indicated in Fig. 9. An absorption band showing the vibrational properties of $\mathrm{Fe}-\mathrm{O}$ bond is observed for in around $477 \mathrm{~cm}^{-1}$ (Gupta et al., 2011). Other iron oxides namely $\mathrm{Fe}_{3} \mathrm{O}_{4}$ and $\mathrm{Fe}_{2} \mathrm{O}_{3}$ were also recorded as peaks at 573-588 $\mathrm{cm}^{-1}$ (Dong et al., 2014; Shu and Wang, 2009; Du et al., 2010). The spectra also indicated the existence of organic groups of antibiotics after adsorption on $\mathrm{M}_{3}-\mathrm{plN}_{2}$. The peaks in the range of $3800-3900 \mathrm{~cm}^{-1}$ correspond to $-\mathrm{OH}$ groups in $\mathrm{TC}-\mathrm{M}_{3}-\mathrm{plN}_{2}, \mathrm{CP}-\mathrm{M}_{3}-$ $\mathrm{plN}_{2}$ and mixed antibiotics loaded- $\mathrm{M}_{3}-\mathrm{plN}_{2}$, indicating the existence of hydroxyl groups on the surface of loaded adsorbents, originated from TC and CP (Ahmed et al., 2015). Those at $1550-1540 \mathrm{~cm}^{-1}$ are the N-H and C-N stretching mode of groups of the three antibiotics (Parikh and Chorover, 2006). The peaks at $2920 \mathrm{~cm}^{-1}$ shows to the $\mathrm{C}-\mathrm{H}$ stretch vibration and peaks at $1520 \mathrm{~cm}^{-1}$ correspond to $\mathrm{C}=\mathrm{O}$, originated from TC and $\mathrm{CP}$ (Ahmed et al., 2015). 


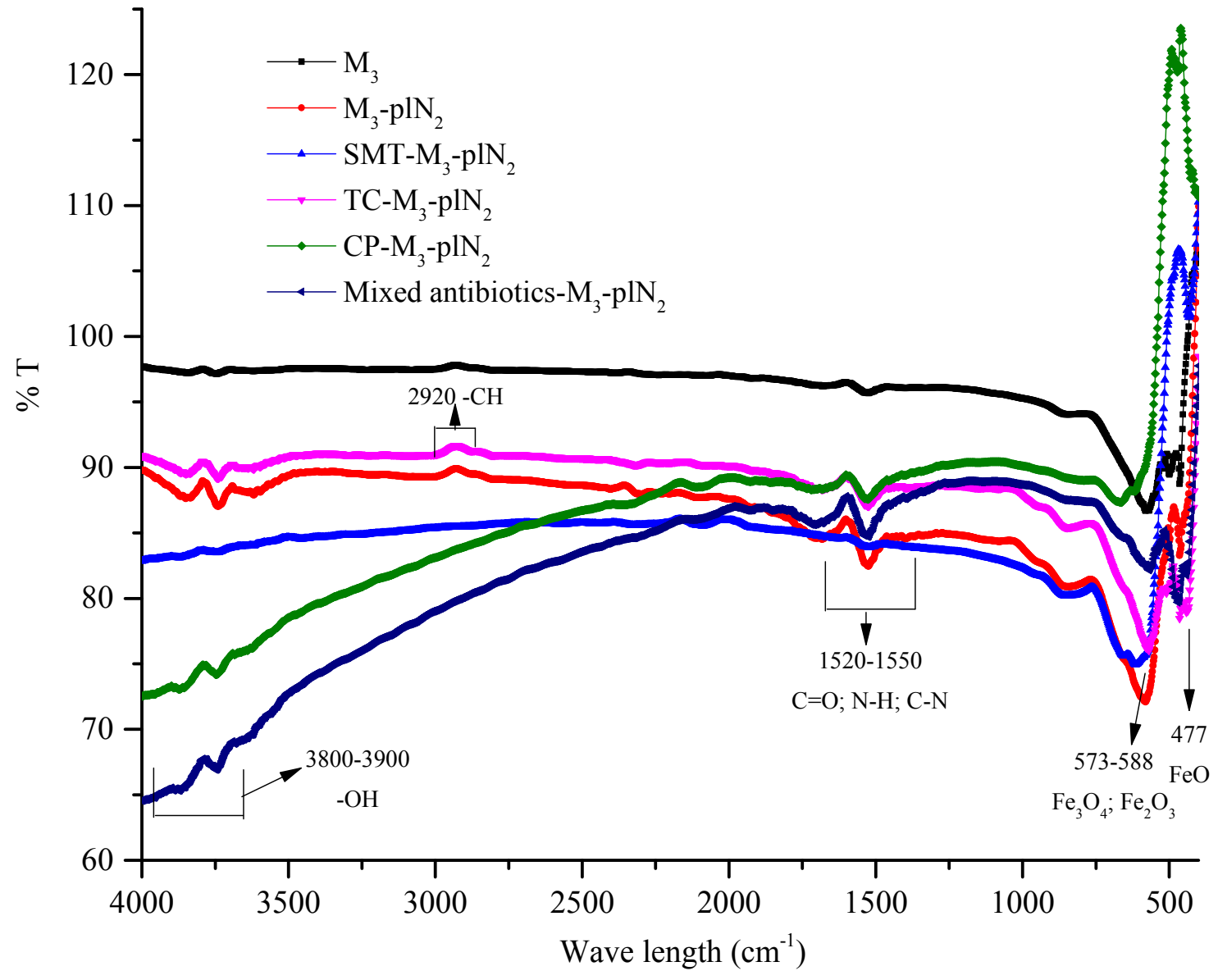

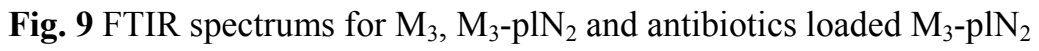

XPS is a surface sensitive method which can determine the binding energy of elements in the top $10 \mathrm{~nm}$ of a sample as shown in the full survey scans of Fig. 10. 


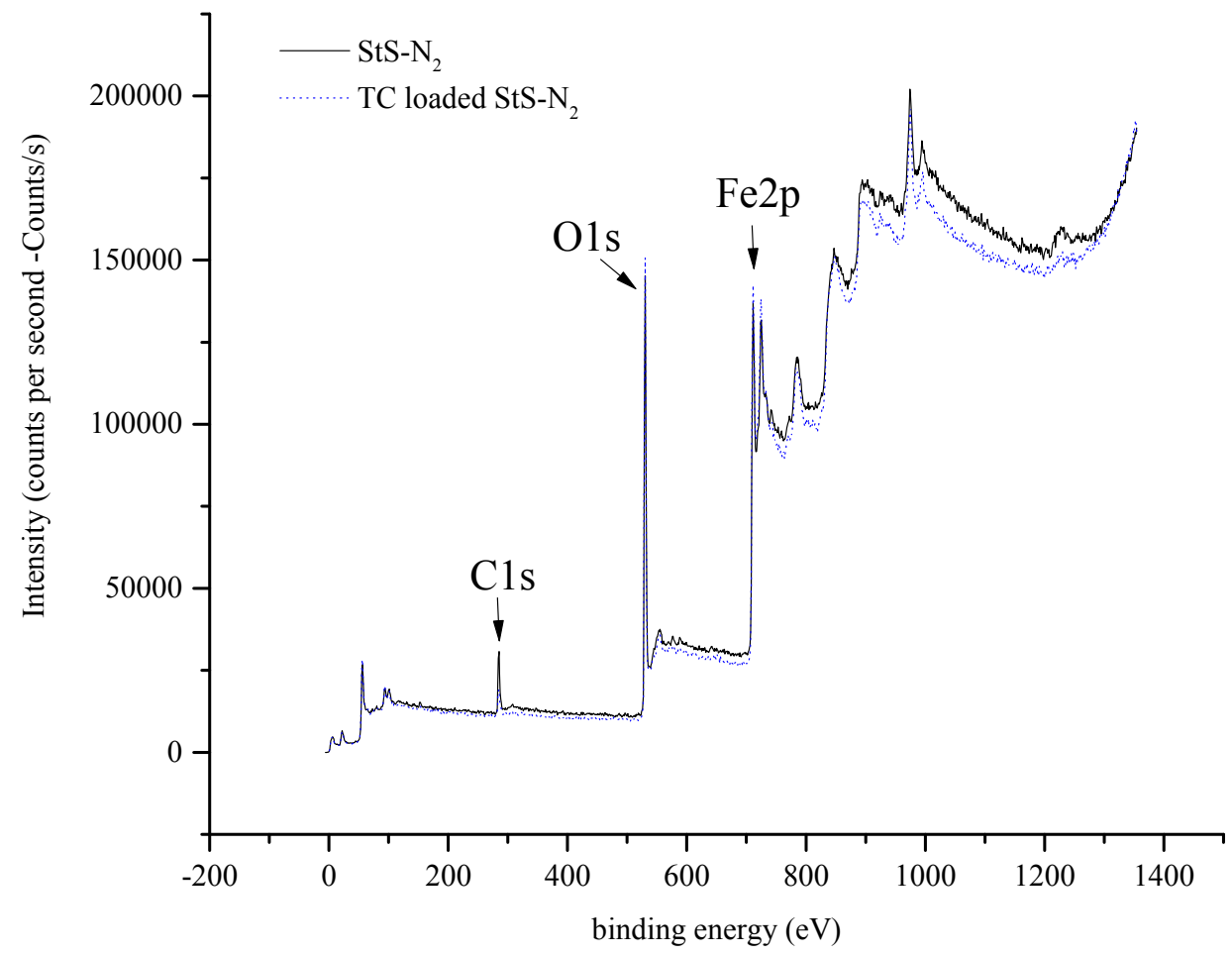

Fig. 10 Full survey of $\mathrm{N}_{2}$ plasma modified steel shavings before and after adsorption

By executing narrow scans in the binding energy regions of the elements, it is possible to relate the peaks in binding energy to chemical bonds, states and those elements' environments.

Starting with the two narrow scans in the C1s region (Fig. 11), displayed here are peaks that are characteristic of adventitious carbon contamination of the adsorbent surface (layer thickness 1-2nm). The typical chemical states of C were C-C at $\sim 284.8 \mathrm{eV}, \mathrm{C}-\mathrm{O}-\mathrm{C}$ at $\sim 286$ $\mathrm{eV}$ and $\mathrm{O}-\mathrm{C}=\mathrm{O}$ at $>288.5 \mathrm{eV}$ bonding (Table 7; Thermo scientific XPS, 2017). 

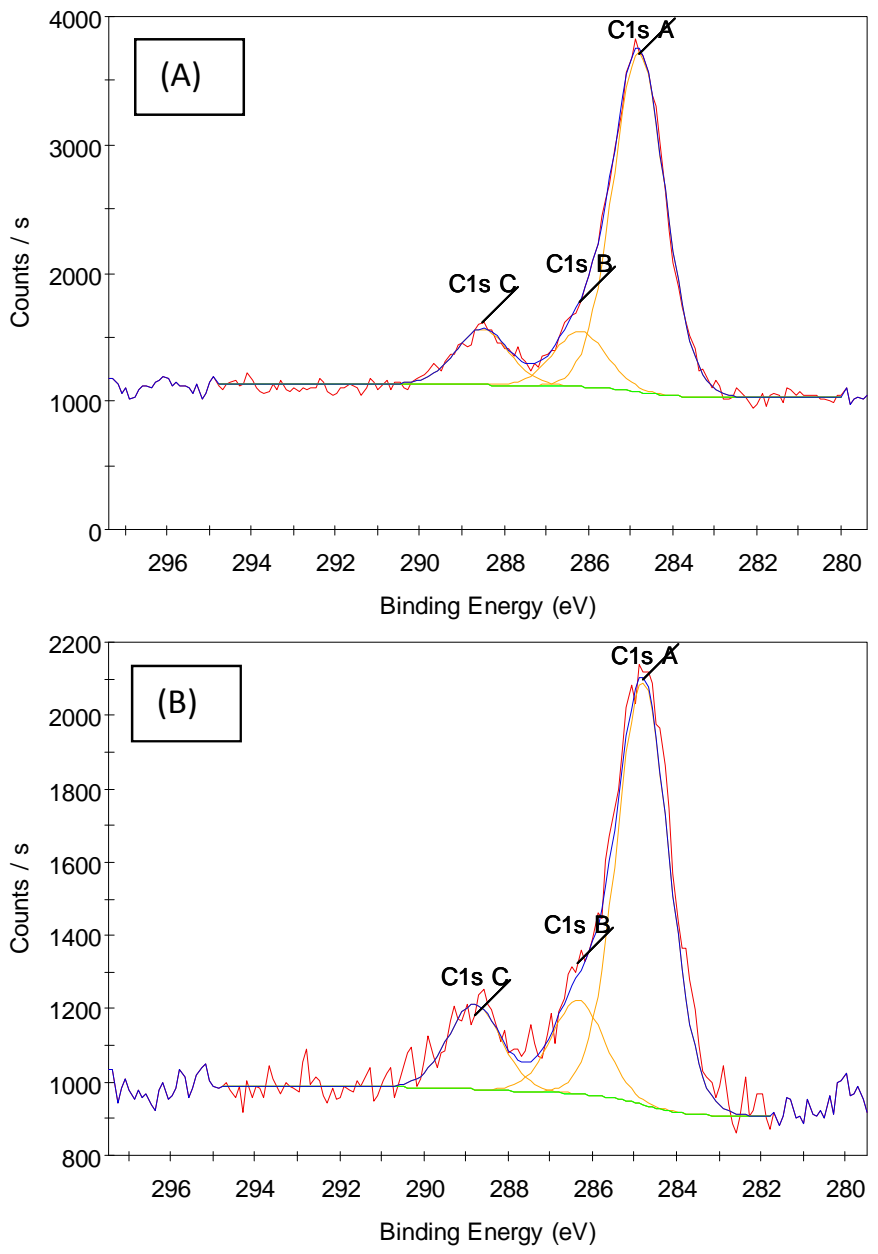

Fig. 11 XPS narrow scan of $\mathrm{C} 1 \mathrm{~s}$ region for $\mathrm{M}_{3}-\mathrm{plN}_{2}$ (A) before adsorption and (B) after adsorption

Table 7 Binding energy, chemical state, relative peak area and atomic percentage of peaks in narrow scan of $\mathrm{C} 1 \mathrm{~s}$ region of the adsorbent before and after adsorption

\begin{tabular}{llllll}
\hline Name & $\begin{array}{l}\text { Spectrum } \\
\text { (Region Peak) }\end{array}$ & $\begin{array}{l}\text { Binding Energy } \\
(\mathbf{e V})\end{array}$ & $\begin{array}{l}\text { Chemical State } \\
\text { C1s A }\end{array}$ & $\begin{array}{l}\text { Relative Peak } \\
\text { Area (CPS.eV) }\end{array}$ & Atomic \% \\
\hline $\mathrm{M}_{3}$-plN 2 & 284.79 & C-C & 4177.22 & 16.19 \\
& C1s B & 286.2 & C-O-C & 687.9 & 2.67 \\
& C1s C & 288.51 & O-C=O & 688.53 & 2.67 \\
TC loaded & C1s A & 284.8 & C-C & 1827.1 & 7.7 \\
$\mathrm{M}_{3}-\mathrm{plN}_{2}$ & C1s B & 286.34 & C-O-C & 403.7 & 1.7 \\
& C1s C & 288.79 & O-C=O & 368.94 & 1.56 \\
\hline
\end{tabular}

Fig. 12 shows that oxygen's chemical states with the adventitious carbon and the metals are presented in the narrow scans in the O1s region. The O1sA peaks $(\sim 529-530 \mathrm{eV})$ in each spectrum are characteristic of metal oxides $\left(\mathrm{Fe}_{2} \mathrm{O}_{3}, \mathrm{Fe}_{3} \mathrm{O}_{4}, \mathrm{FeO}\right)$ while the $\mathrm{O} 1 \mathrm{sB}$ and $\mathrm{O} 1 \mathrm{sC}$ are characteristic of adventitious carbon $\mathrm{C}-\mathrm{O}(\sim 531.5-532 \mathrm{eV})$ and $\mathrm{C}=\mathrm{O}(\sim 533 \mathrm{eV})$ bonding, respectively (Table 8; Thermo scientific XPS, 2017). 

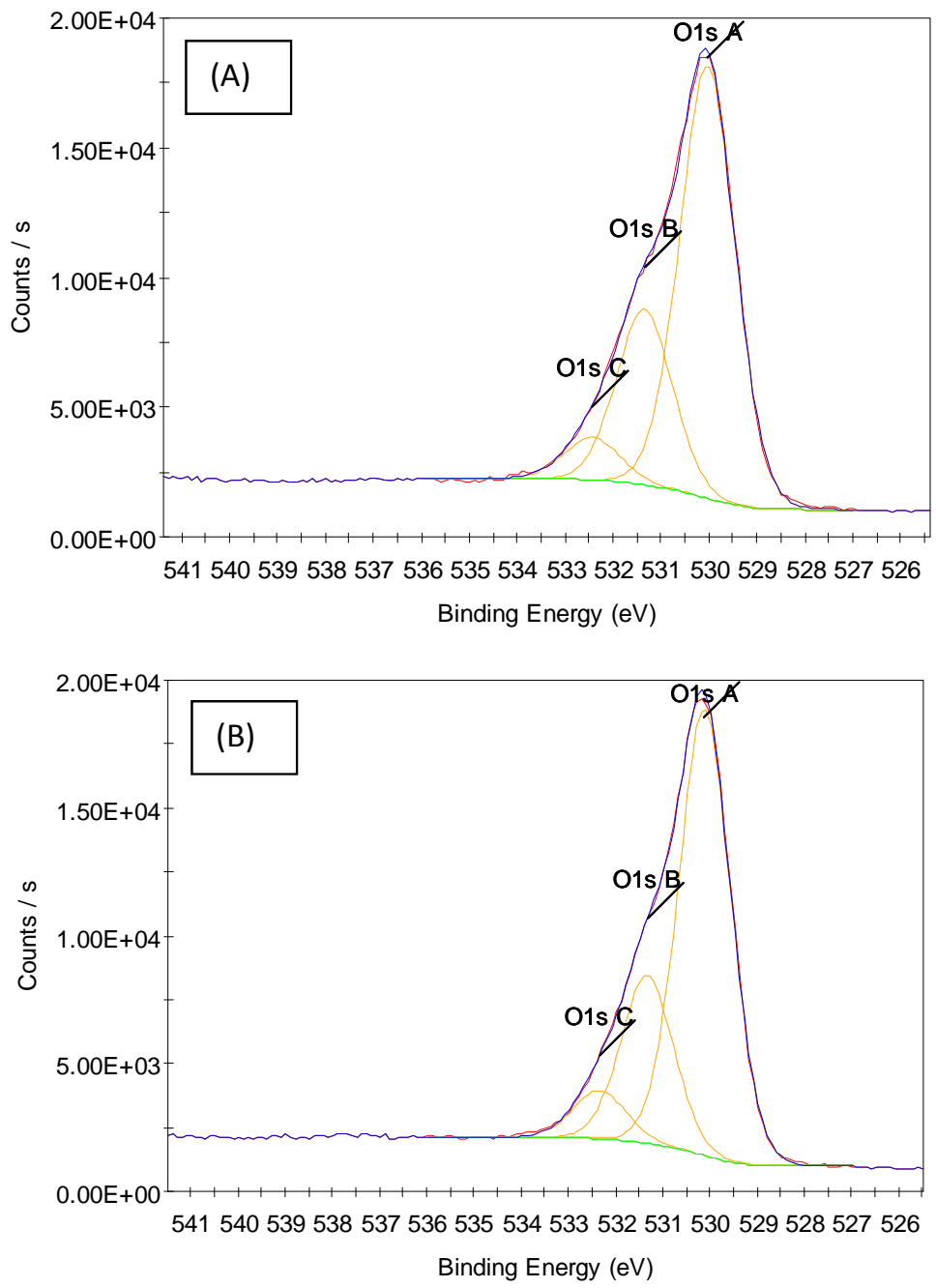

Fig. 12 XPS narrow scan of O1s region for $\mathrm{M}_{3}-\mathrm{plN}_{2}$ (A) before adsorption and (B) after adsorption

Table 8 Binding energy, chemical state, relative peak area and atomic percentage of peaks in narrow scan of $\mathrm{O} 1 \mathrm{~s}$ region of the adsorbent before and after adsorption

\begin{tabular}{llllll}
\hline Name & $\begin{array}{l}\text { Spectrum } \\
\text { (Region Peak) }\end{array}$ & $\begin{array}{l}\text { Binding Energy } \\
(\mathbf{e V})\end{array}$ & $\begin{array}{l}\text { Chemical State } \\
\text { O1s A }\end{array}$ & $\begin{array}{l}\text { Relative Peak } \\
\text { Area (CPS.eV) }\end{array}$ & Atomic \% \\
\hline $\mathrm{M}_{3}-\mathrm{plN}_{2}$ & O1s B & 531.34 & O-metal oxides & 24427.48 & 33.84 \\
& O1s C & 532.44 & $\mathrm{C}-\mathrm{O}$ & 9909.97 & 13.73 \\
& C1s $=\mathrm{O}$ & 2407.51 & 3.34 \\
$\mathrm{TC}_{\text {loaded }}$ & O1s A & 530.12 & O-metal oxides & 24518.67 & 36.92 \\
$\mathrm{M}_{3}-\mathrm{plN}_{2}$ & O1s B & 531.33 & $\mathrm{C}-\mathrm{O}$ & 9242.38 & 13.92 \\
& O1s C & 532.34 & $\mathrm{C}=\mathrm{O}$ & 2650.33 & 3.99 \\
\hline
\end{tabular}

The binding energy of an element increases when its valence state also increases. This was demonstrated by the binding energy separation of the Fe2p3/2A and Fe2p3/2B peaks in all spectra in Fig. 13, suggesting a mixed oxide of both $\mathrm{Fe}^{3+}$ and $\mathrm{Fe}^{2+}$ which is $\mathrm{Fe}_{3} \mathrm{O}_{4}$. This oxide 
is the dominant oxide present for both before and after adsorption processes (Table 9). The other two constituents - Fe2p3/2C and Fe2p3/2D in all spectra - are representative of $\mathrm{Fe}^{2+}$ and $\mathrm{Fe}^{3+}$ in their other separate oxides states of $\mathrm{FeO}$ and $\mathrm{Fe}_{2} \mathrm{O}_{3}$, respectively. These oxides are mainly responsible for the adsorption of SMT, TC and CP on raw and modified steel shavings. Fig. 13 does not show the spectrum peak at $\sim 706.7 \mathrm{eV}$ binding energy, which indicates the chemical state of zero-valent iron $\left(\mathrm{Fe}^{0}\right)$ (Thermo scientific XPS, 2017). Since the detected limitation of XPS technique is $10 \mathrm{~nm}$ in the top surface of the material, it can be assumed that the $\mathrm{Fe}^{0}$ core of the adsorbent was covered by an iron oxide film that was thicker than $10 \mathrm{~nm}$.

Based on the XPS results and what previous studies have found, the mechanisms that could be proposed for the removal of antibiotics are: SMT: hydrogen bonding; TC: electrostatic and non- electrostatic interaction; and CP removal: redox reaction (Qiang et al., 2013; Chen et al., 2011; Nie et al., 2015; Xia et al., 2014). Qiang et al. (2013) proposed three kinds of hydrogen bonding between the nitrogen of the aniline, sulfinol or pyrimidine group of SMT and the surface hydroxyl group of FeM48 being the major driving force for adsorption. Additionally, the л-л electron-donor acceptor interaction between SMT (л-electroneacceptor) and the adsorbent (л-еlectronedonor) also promoted adsorption (Qiang et al., 2013). Chen et al. (2011) confirmed that the adsorption pathway of TC on PVP-nano zero-valent iron included electrostatic interactions and Fe-TC complexation reactions. Meanwhile the removal of CP as reported by Nie et al. (2015) and Xia et al. (2014) was redox reaction. 

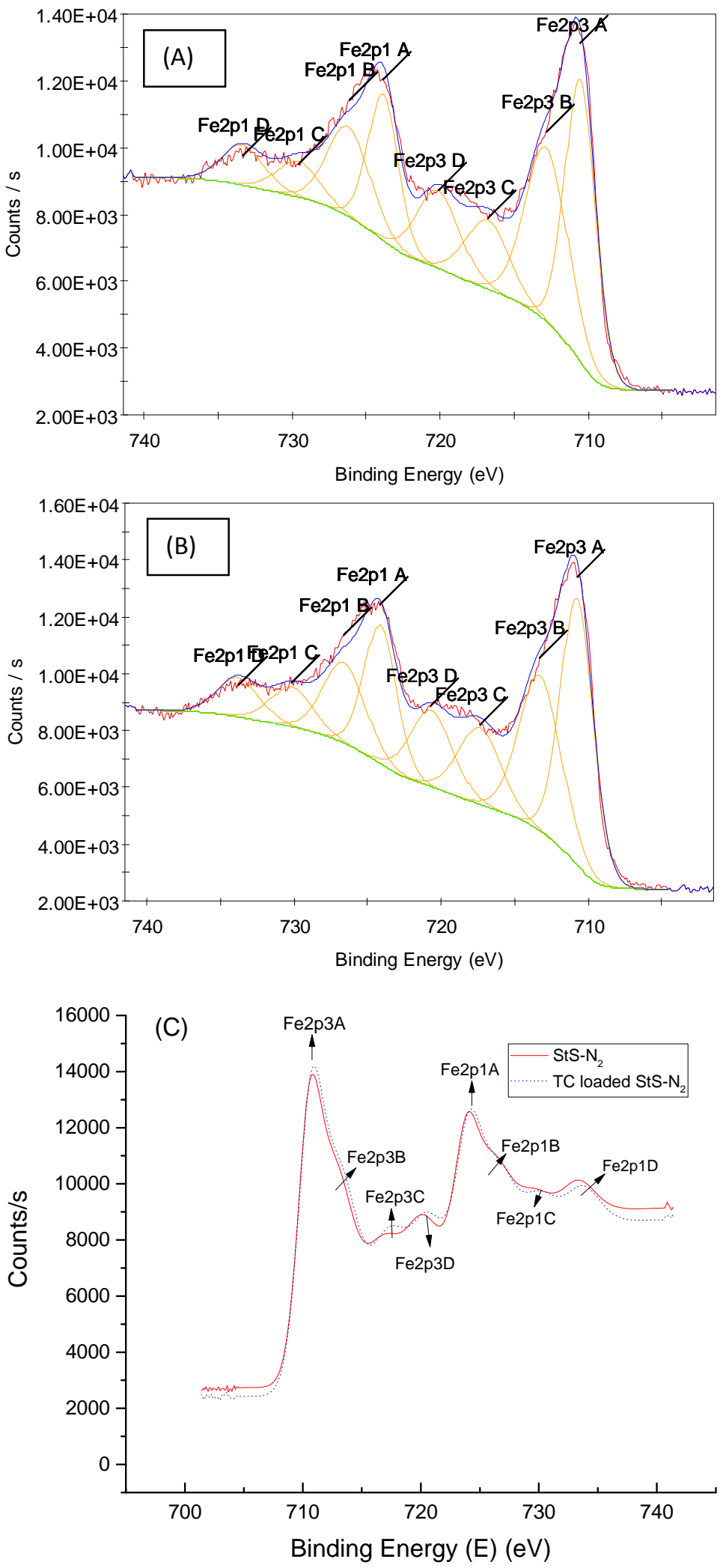

Fig. 13 XPS narrow scan of $\mathrm{Fe} 2 \mathrm{p}$ region for $\mathrm{M}_{3}-\mathrm{plN}_{2}$ (A) before adsorption; (B) after adsorption; (C) combined strecpums of before and after adsorption 
Table 9 Binding energy, chemical state, relative peak area and atomic percentage of peaks in narrow scan of $\mathrm{Fe} 2 \mathrm{p} 3 / 2$ region of the adsorbent before and after adsorption

\begin{tabular}{|c|c|c|c|c|c|}
\hline Name & $\begin{array}{l}\text { Spectrum } \\
\text { (Region Peak) }\end{array}$ & $\begin{array}{l}\text { Binding } \\
\text { Energy }(\mathrm{eV})\end{array}$ & Chemical State & $\begin{array}{l}\text { Relative Peak } \\
\text { Area (CPS.eV) }\end{array}$ & Atomic \% \\
\hline \multirow{4}{*}{$\mathrm{M}_{3}-\mathrm{plN}_{2}$} & Fe2p3 A & 710.54 & $\mathrm{Fe}_{3} \mathrm{O}_{4} / \mathrm{Fe}^{2+}$ & 21785.43 & 9.03 \\
\hline & $\mathrm{Fe} 2 \mathrm{p} 3 \mathrm{~B}$ & 712.8 & $\mathrm{Fe}_{3} \mathrm{O}_{4} / \mathrm{Fe}^{3+}$ & 18998.32 & 7.88 \\
\hline & $\mathrm{Fe} 2 \mathrm{p} 3 \mathrm{C}$ & 716.79 & $\mathrm{FeO} / \mathrm{Fe}^{2+}$ & 7546.61 & 3.13 \\
\hline & Fe2p3 D & 720.12 & $\mathrm{Fe}_{2} \mathrm{O}_{3} / \mathrm{Fe}^{3+}$ & 8492.22 & 3.53 \\
\hline TC loaded & $\mathrm{Fe} 2 \mathrm{p} 3 \mathrm{~A}$ & 710.77 & $\mathrm{Fe}_{3} \mathrm{O}_{4} / \mathrm{Fe}^{2+}$ & 26057.06 & 11.74 \\
\hline \multirow[t]{3}{*}{$\mathrm{M}_{3}-\mathrm{plN}_{2}$} & Fe2p3 B & 713.26 & $\mathrm{Fe}_{3} \mathrm{O}_{4} / \mathrm{Fe}^{3+}$ & 19896.5 & 8.97 \\
\hline & $\mathrm{Fe} 2 \mathrm{p} 3 \mathrm{C}$ & 717.35 & $\mathrm{FeO} / \mathrm{Fe}^{2+}$ & 9810.93 & 4.43 \\
\hline & Fe2p3 D & 720.65 & $\mathrm{Fe}_{2} \mathrm{O}_{3} / \mathrm{Fe}^{3+}$ & 9747.22 & 4.4 \\
\hline
\end{tabular}

\section{Conclusion}

This study demonstrated that the raw and modified steel shavings, an industrial waste, did effectively remove the antibiotics SMT, TC and CP from aqueous solution. Nitrogen plasma modification has cleaned and improved surface area, pore volume of steel shavings and then increased adsorption capacity of the adsorbent for the antibiotics. The antibiotics' maximum Langmuir sorption capacity declined in the following order: $\mathrm{CP}>\mathrm{SMT}>\mathrm{TC}$ on both raw and modified StS. The sorption of the pollutants on the adsorbents reached equilibrium in an hour. Acidic solution was optimal for removing SMT and CP while the adsorption of TC was most efficient at neutral $\mathrm{pH}$ value. The proposed mechanisms for removing SMT, TC and CP by raw and nitrogen plasma modified steel shavings were hydrogen bonding, electrostatic and non- electrostatic interactions and redox reaction. In order to apply steel shavings as an adsorbent in real wastewater treatment, studies in ABs removal from real wastewater at pilot scales need to be implemented.

\section{Acknowledgment}

The authors acknowledge the support of Centre for Technology in Water and Wastewater (CTWW), School of Civil and Environmental Engineering, Faculty of Engineering and Information Technology. The technical support from Microstructure Analysis Unit, Faculty of Science, UTS and the Australian Award Scholarships are also grateful. The authors are 
grateful to the research collaboration between UTS and Shanghai Advanced Research Institute/Tianjin Polytechnic University.

\section{References}

1. Adams, C., Wang, Y., Loftin, K., Meyer, M., 2002. Removal of antibiotics from surface and distilled water in conventional water treatment processes. J. Environ. Eng. 128, 253260.

2. Ahmed, M.B., Zhou, J.L., Ngo, H.H., Guo, W., 2015. Adsorptive removal of antibiotics from water and wastewater: progress and challenges. Sci. Total. Environ. 532, 112-126.

3. Ahmed, M.B., Zhou, J.L., Ngo, H.H., Guo, W., Johir, M.A.H., Sornalingam, K., 2017. Single and competitive sorption properties and mechanism of functionalized biochar for removing sulfonamide antibiotics from water. Chem. Eng. J. 311, 348-358.

4. Aredes, S., Klein, B., Pawlik, M., 2012. The removal of arsenic from water using natural iron oxide minerals. J. Clean. Prod. 29, 208-213.

5. Aust, M.O., Thiele-Bruhn, S., Seeger, J., Godlinski, F., Meissner, R., Leinweber, P., 2010. Sulfonamides leach from sandy loam soils under common agricultural practice. Water Air Soil Poll. 211, 143-156.

6. Boparai, H.K., Joseph, M., O'Carroll, D.M., 2011. Kinetics and thermodynamics of cadmium ion removal by adsorption onto nano zerovalent iron particles. J. Hazard. Mater. 186, 458-465.

7. Chen, H., Luo, H., Lan, Y., Dong, T., Hu, B., Wang, Y., 2011. Removal of tetracycline from aqueous solutions using polyvinylpyrrolidone (PVP-K30) modified nanoscale zero valent iron. J. Hazard. Mater. 192, 44-53.

8. Cundy, A.B., Hopkinson, L., Whitby, R.L., 2008. Use of iron-based technologies in contaminated land and groundwater remediation: A review. Sci. Total. Environ. 400, 4251.

9. Daughton, C.G., Ternes, T.A., 1999. Pharmaceuticals and personal care products in the environment: agents of subtle change? Environ. Health Perspect. 107, 907.

10. Deiries, S., Silber, A., Iwert, O., Hummel, E., Lizon, J. L., 2005. Plasma cleaning: a new method of ultra-cleaning detector cryostats. Beletic JE, Beletic JW 8c Amico P (eds) Scientific Detectors for Astronomy. Springer. Netherlands, 129-136. 
11. Dong, L., Peng, H., Wang, S., Zhang, Z., Li, J., Ai, F., Zhao, Q., Luo, M., Xiong, H., Chen, L., 2014. Thermally and magnetically dual-responsive mesoporous silica nanospheres: preparation, characterization, and properties for the controlled release of sophoridine. J. Appl. Polym. Sci. 131, 40477.

12. Du, N., Xu, Y., Zhang, H., Zhai, C., Yang, D., 2010. Selective synthesis of $\mathrm{Fe}_{2} \mathrm{O}_{3}$ and $\mathrm{Fe}_{3} \mathrm{O}_{4}$ nanowires via a single precursor: a general method for metal oxide nanowires. Nanoscale Res. Lett. 5, 1295.

13. Ghauch, A., Tuqan, A., Assi, H.A., 2009. Antibiotic removal from water: elimination of amoxicillin and ampicillin by microscale and nanoscale iron particles. Environ. Pollut. 157, 1626-1635.

14. Gheju, M., Balcu, I., 2011. Removal of chromium from $\mathrm{Cr}$ (VI) polluted wastewaters by reduction with scrap iron and subsequent precipitation of resulted cations. J. Hazard. Mater. 196, 131-138.

15. Gupta, V.K., Agarwal, S., Saleh, T.A., 2011. Chromium removal by combining the magnetic properties of iron oxide with adsorption properties of carbon nanotubes. Water Res. 45, 2207-2212.

16. Homem, V., Santos, L., 2011. Degradation and removal methods of antibiotics from aqueous matrices-a review. J. Environ. Manage. 92, 2304-2347.

17. Hua, M., Zhang, S., Pan, B., Zhang, W., Lv, L., Zhang, Q., 2012. Heavy metal removal from water/wastewater by nanosized metal oxides: a review. J. Hazard. Mater. 211, $317-$ 331.

18. Liao, P., Zhan, Z., Dai, J., Wu, X., Zhang, W., Wang, K., Yuan, S., 2013. Adsorption of tetracycline and chloramphenicol in aqueous solutions by bamboo charcoal: a batch and fixed-bed column study. Chem. Eng. J. 228, 496-505.

19. Nguyen, T.A.H., Ngo, H.H., Guo, W.S., Zhou, J.L., Wang, J., Liang, H., Li, G., 2014. Phosphorus elimination from aqueous solution using 'zirconium loaded okara'as a biosorbent. Bioresource Technol. 170, 30-37.

20. Nie, M., Yan, C., Li, M., Wang, X., Bi, W., Dong, W., 2015. Degradation of chloramphenicol by persulfate activated by $\mathrm{Fe}^{2+}$ and zerovalent iron. Chem. Eng. J. 279, 507-515.

21. Parikh, S.J., Chorover, J., 2006. ATR-FTIR spectroscopy reveals bond formation during bacterial adhesion to iron oxide. Langmuir 22. 8492-8500. 
22. Pouran, S.R., Raman, A.A.A., Daud, W.M.A.W., 2014. Review on the application of modified iron oxides as heterogeneous catalysts in Fenton reactions. J. Clean. Prod. 64, 24-35.

23. Pubchem, $2017 . \quad$ Open chemistry database. https://pubchem.ncbi.nlm.nih.gov/compound/5959\#section=Top (accessed 01.03.17).

24. Qiang, Z., Bao, X., Ben, W., 2013. MCM-48 modified magnetic mesoporous nanocomposite as an attractive adsorbent for the removal of sulfamethazine from water. Water Res. 47, 4107-4114.

25. Rangsivek, R., Jekel, M.R., 2005. Removal of dissolved metals by zero-valent iron (ZVI): Kinetics, equilibria, processes and implications for stormwater runoff treatment. Water Res. 39, 4153-4163.

26. Sapkota, A., Sapkota, A.R., Kucharski, M., Burke, J., McKenzie, S., Walker, P., Lawrence, R., 2008. Aquaculture practices and potential human health risks: current knowledge and future priorities. Environ. Int. 34, 1215-1226.

27. Sengil, I.A., Özacar, M. 2008. Biosorption of $\mathrm{Cu}$ (II) from aqueous solutions by mimosa tannin gel. J. Hazard. Mater. 157, 277-285.

28. Shu, Z., Wang, S., 2009. Synthesis and characterization of magnetic nanosized $\mathrm{Fe}_{3} \mathrm{O}_{4} / \mathrm{MnO}_{2}$ composite particles. J. Nanomater. 2009, 2.

29. Thermo scientific XPS, 2017. XPS reference. http://xpssimplified.com/periodictable.php (accessed 28.02.17).

30. Wegst-Uhrich, S.R., Navarro, D.A., Zimmerman, L., Aga, D.S., 2014. Assessing antibiotic sorption in soil: a literature review and new case studies on sulfonamides and macrolides. Chem. Cent. J. 8, 5.

31. Xia, S., Gu, Z., Zhang, Z., Zhang, J., Hermanowicz, S.W., 2014. Removal of chloramphenicol from aqueous solution by nanoscale zero-valent iron particles. Chem. Eng. J. 257, 98-104. 